KEYWORDS

Commodities

Exports

Commodity prices

Price indices

Statistical data

Latin America

Omar D. Bello

Economic Affairs Officer, Disaster

Evaluation Unit. Sustainable

Development and Human

Settlements Division, ECLAC

omar.bello@cepal.org

Fernando Cantú

Economic Affairs Officer. Economic

Development Division, ECLAC

. fernando.cantu@cepal.org

Rodrigo Heresi

Consultant, Economic Development

Division, ECLAC

. rheresig@gmail.com
CEPAL REVIEW 103 A PRIL 2011

\section{Latin America: variability and persistence in commodity prices}

\author{
Omar D. Bello, Fernando Cantú and Rodrigo Heresi
}

$\mathrm{T}$

his article describes variability and persistence in the real prices

of Latin America's main export commodities. The results of this research show that real price index series for a large majority of commodities display high persistence to shocks; and, as they repeatedly suffer both positive and negative shocks, all commodities display multiple cycles. The rising price phase that began in the early 2000s differed from previous upswings in terms of its duration, nature and the number of products involved. As this is a just one cycle, however, it is impossible to claim that a definitive change has occurred in the cyclical pattern of commodity price series. 


\section{I}

\section{Introduction}

The variability of real commodity price series has had significant effects on various dimensions of the Latin American economies. In general, the trade balance, the budget balance, inflation, the real exchange rate and economic growth in the different countries of the region have often been affected by commodity price cycles; and this has posed challenges for the economic policies applied in these countries. This is particularly true in economies whose export basket is highly concentrated on commodities, or whose fiscal accounts rely heavily on revenue obtained from commodities.

Despite efforts to diversify the productive structure and export basket, the region still relies heavily on commodity exports. ${ }^{1}$ Furthermore, a large proportion of the region's manufacturing exports are based on natural resources, and, given their low level of value-added, they are also exposed to international commodity-price fluctuations. For example, on average for the period 2000-2006, and for the regional aggregate of Latin America (encompassing 16 countries), $45 \%$ of total exports consist of commodities and almost half of the rest $(47 \%)$ are natural-resource-intensive manufactures. ${ }^{2}$ The country-by-country picture is quite similar, albeit with certain exceptions, such as Brazil and Mexico, whose export baskets are somewhat more diversified, the corresponding figures being $28.5 \%$ and $35 \%$ in the case of Brazil, and $14.1 \%$ and $7.8 \%$ in the case of Mexico. The region's import basket is heavy in oil and hydrocarbon products: in 2007, oil represented over $20 \%$ of total imports in Chile, Honduras, Nicaragua and Uruguay, and over $10 \%$ in the case of Brazil, Costa Rica, Ecuador, El Salvador, Guatemala, Panama, Paraguay and Peru. In contrast, oil-producing countries such as the Bolivarian Republic of Venezuela, Colombia, Ecuador and Mexico do not share this problem. The oil price

\footnotetext{
1 See ECLAC (2007 and 2008).

2 Includes Argentina, the Bolivarian Republic of Venezuela, Brazil, Chile, Colombia, Costa Rica, Ecuador, El Salvador, Guatemala, Honduras, Nicaragua, Panama, Paraguay, Peru, the Plurinational State of Bolivia and Uruguay. Excludes Mexico, because this country accounted for about $40 \%$ of the region's total exports in 2006, a large proportion of which correspond to goods produced by the maquila industry, which are classified as manufactures but contain little value-added. Mexico's large weight and its low value-added manufactures would obscure the point being made with the aggregate figure, namely the high commodity concentration of the region's export basket.
}

also has the potential to affect domestic price indices, as happened in 2008.

Similarly, in some of the region's countries, fiscal income obtained from commodities (production, taxation or both) accounts for a large share of total income in this sector. ${ }^{3}$ In the case of the Plurinational State of Bolivia, for example, hydrocarbon taxes accounted for $34 \%$ of total fiscal income, or $11 \%$ of gross domestic product (GDP). In Chile, copper revenues contributed by the National Copper Corporation (CODELCO), a Stateowned mining company, provided $18 \%$ of total central government income ( $5 \%$ of GDP), not counting taxes levied on private mining companies operating in the country. In Mexico, government income obtained from oil is more than a third (35\%) of total fiscal income (9\% of GDP); and the equivalent figures in Colombia and Ecuador are $14 \%$ and $25 \%$, respectively. The Bolivarian Republic of Venezuela is the most extreme case in the region, where over half of fiscal income is obtained from oil.

This paper aims to describe the variability displayed by the prices of the main Latin American commodities in the period 1960-2009, when the real prices of these products have risen and fallen in different episodes. ${ }^{4}$ Three important aspects of variability are analysed: nonspurious rises and falls in prices, the precise definition of the corresponding cycles and the persistence of price shocks. In the first case, the concepts of net price increases and net price falls are used. Net prices increases (falls) occur when the price quoted in a given quarter is above (below) the maximum (minimum) of the six previous quarters. The length of the window used aims to eliminate spurious price movements. In relation to the second issue, precise dates were determined for real commodity price cycles in Latin America, using a procedure based on the Bry-Boschan algorithm, which makes it possible to determine the local maximum and minimum of the series. A cycle is a period consisting of a rise and subsequent fall in prices, with the rise (fall) defined as a period that starts with a local minimum (maximum) and ends with a local maximum (minimum).

\footnotetext{
3 The figures quoted correspond to the average for 2003-2007.

4 The database used contains 27 real commodity price indices, and seven groupings thereof, with quarterly figures spanning the first quarter of 1960 to the fourth quarter of 2009.
} 
Lastly, the persistence of a price shock is measured by the median-unbiased estimator of auto-regressive models proposed by Andrews and Chen (1994), and an estimator of the "memory" parameter of a fractionally integrated auto-regressive moving average (ARMA) model.

The key results of the research are as follows:

(i) All commodities in the sample display more net price falls than net increases, although the opposite was true for most commodities in 2000-2009;

(ii) The price-fall phases tend to last longer on average (number of quarters) than the rises, but the upswing phase in the period 2000-2009 is unprecedented in terms of duration and magnitude; and

(iii) Commodity price shocks are generally highly persistent.

The rest of this article is organized as follows: section II briefly discusses the main stylized facts of commodity price movements. Section III presents the results of non-spurious price variations and estimations of the cycle. Section IV estimates the persistence of the aforementioned shocks, their application, and the results obtained. Lastly, section V, provides an assessment.

\section{II}

\section{Literature review and stylized facts}

The importance of commodity prices for the world economy has spawned a wide-ranging literature, from which a number of stylized facts can be distilled. Firstly, commodity prices do not display a clear trend (see Grilli and Yang, 1988; Cuddington, 1992; Deaton and Laroque, 1992; Deaton, 1999; Cashin and McDermott, 2002; Cuddington, Ludema and Jayasuriya, 2002; Ocampo and Parra, 2003). According to Cashin and McDermott (2002), even where there is a negative trend, this is usually relatively insignificant in practical terms, since the trend is small in absolute terms and is generally dominated by the variability of the series, as will be analysed in terms of the second stylized fact. All of the above-mentioned authors reached the same conclusion, using databases that include real aggregate and individual commodity-price indices, spanning between 80 and 140 years, and different econometric methods to characterize the trends.

Secondly, primary product prices are characterized by sudden and significant rises and falls, which gives them a high variance. The real price series for oil, copper, coffee and sugar illustrate this idea (see figure 1). The abrupt increases in oil and coffee prices correspond to negative supply shocks. In the case of oil, in the first quarter of 1974 , the price rose by $273 \%$ from its level in the last quarter of 1973; and in 1979 it rose again, this time by $102 \%$ in relation to its 1978 level. These events reflected political factors that generated a sharp supply constraint (Deaton, 1999). In the case of agricultural goods, a widely quoted example is coffee, for which the price rose by $60 \%$ in real terms between mid-1976 and mid-1977, following a period of frosts that substantially depleted the coffee harvest in Brazil with a major impact on world supply.

Thirdly, Deaton and Laroque (1992) detect high autocorrelation in the different series, using an annual database spanning 1900-1987 which includes 11 agricultural and two mineral products. Cuddington (1992), Deaton (1999) and Cashin, Liang and McDermott (2000) also confirm that the series are highly persistent.

Lastly, while Pyndick and Rotemberg (1990) find that the prices of very different commodities are highly correlated, Cashin, McDermott and Scott (1999b) do not detect such correlations using data later than 1970, so they conclude that the earlier authors' findings reflect the mid-1970s oil shock.

Sections III and IV consider the second stylized fact further in the light of the database, and the third on the basis of the concepts and estimators of persistence used. 
FIGURE 1

Real price indices: selected products 1960 Q1 - 2009 Q4

(Base year $2000=100$ )

Sugar
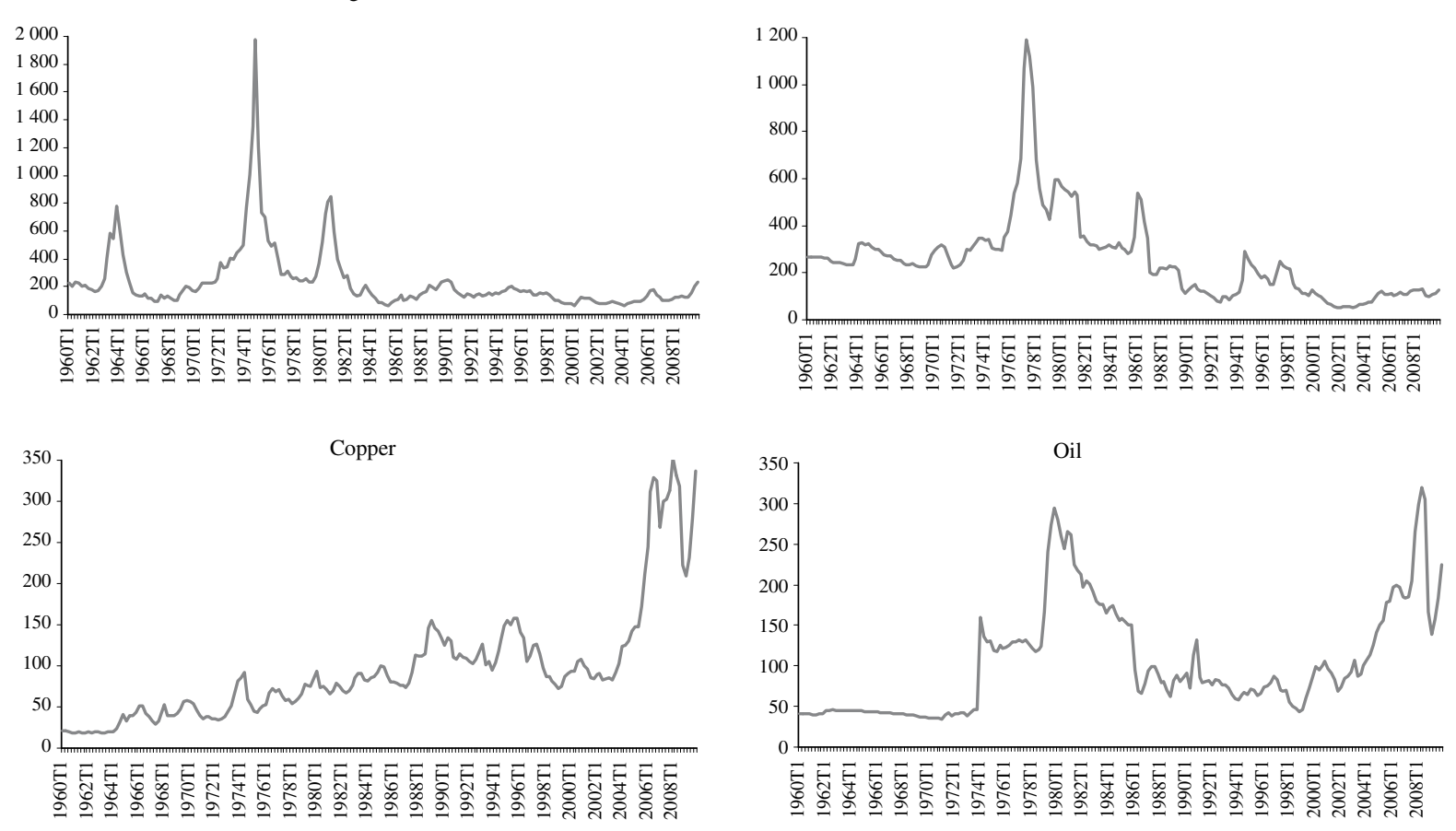

Source: prepared by the author on the basis of the commodity price statistics published by the United Nations Conference on Trade and Development (UNCTAD).

Note: The letter T indicates the quarter (trimestre) of the year in question; for example 1969 T4 refers to the fourth quarter of 1969.

\section{III}

\section{The variability of real commodity-price indices}

To analyse the fluctuations of commodity-price indices a database was used containing 27 real price indices of the main commodities exported by Latin America, and seven groups of those commodities, with quarterly figures covering the period from the first quarter of 1960 to the fourth quarter of $2009 .{ }^{5}$ The groupings are the general index, food products, agricultural and mineral raw materials, and metals. The general index covers all commodities considered in the database source. ${ }^{6}$ The

\footnotetext{
${ }^{5}$ Quarterly data were chosen to eliminate part of the noise that could be generated by real price indices and for future applications that combine with the country's quarterly macroeconomic data.

6 Commodity price statistics published by the United Nations Conference on Trade and Development (UNCTAD).
}

food product aggregate contains three subgroups: food, tropical drinks, and oils and oilseeds. The series were seasonally adjusted using the tramo-seats method. ${ }^{7}$

With regard to fluctuations, this paper focused on two related issues: firstly, sustained increases and sustained falls in commodity prices, given their macroeconomic effect (the concept of net price increases and net price

\footnotetext{
7 All of the time series were seasonally adjusted using the tramoseats method, an algorithm used for prediction, correction of outlying values, seasonal adjustment, estimation of calendar effects, trend-cycle estimation, and other uses. For this purpose, the Demetra software was used with automatically chosen parameters. This software was developed by the Statistical Office of the European Communities (Eurostat).
} 
falls was used for this purpose); and secondly, the sequence of falls and rises in commodity prices, in other words their cycles.

\section{Net price increases and falls}

This paper records a net price increase in a given quarter $t$ if the current-quarter price $P_{t}$ is higher than the maximum of the six previous quarters. ${ }^{8}$ Italso considers that there is a net price fall in a given quarter $t$ if $P_{t}$ is below the minimum of the six previous quarters.

These concepts and their application extend the work of Hamilton (1996) in two directions. Firstly, a net price fall is defined, because the only purpose of the aforementioned study was to analyse the effect of net increases in the price of oil on economic activity in the United States. The present research is also interested in analysing falls in commodity prices, because, as noted above, downward price movements are recurrent in commodity-price series and have significant macroeconomic consequences for certain Latin American countries.

Secondly, the definition used in this article is stricter, because six quarters are used instead of four as a criterion for deciding whether a net price increase or fall occurred in a given quarter. ${ }^{9}$ The comparison period is also lengthened to isolate price movements that could have macroeconomic effects, in the belief that such repercussions affect the decisions of economic agents (public and private sector) if they last for at least six quarters. A six-quarter period also makes it possible to filter out spurious price variations.

Using these definitions each period of the time series used can be divided into three categories: net price increases, net price falls, and periods that cannot be characterized by either of these movements.

\section{(a) Results for the entire sample}

Table 1 shows the number of net price increases and net price falls occurring in each decade. The first salient point is that in the period 1960-2009, 20 of the

\footnotetext{
${ }^{8}$ Hamilton (1996) defines a net price increase as a situation in which the price in a given quarter exceeds the maximum price of the four preceding quarters. The author uses this definition to study upswings in the oil market. He does not target his study on price falls, arguing that only oil price increases have a macroeconomic repercussions for the United States economy. Using quarterly data for the period running from the first quarter of 1948 to the second quarter of 1994, he concludes that net increases in the price of oil occurred in the period 1973-1981, and then again in 1989-1992.

${ }^{9}$ Bello and Heresi (2008) performed this exercise over eight quarters, with very similar results to those presented in this study.
}

27 real commodity-price indices in the sample reported more net price falls than net increases. ${ }^{10}$ This was also true for all groupings in the sample; for example, the general price index of all commodities reported 41 net increases and 56 net falls.

The groupings whose real price indices posted net increases most frequently were minerals and metals, and oils and oil seeds, with 49 and 45 , respectively. The individual commodity-price indices with the largest number of net increases were lead (54), fish meal (54) and copper (47). The groupings that recorded the largest number of net price-fall periods were agricultural raw materials and minerals and metals, with 58. Iron was the individual commodity whose real price index recorded the largest number of periods with net falls (86), followed by tobacco and rubber, with 67 and 66, respectively.

The difference between the number of net price falls and increases varied by decade. In the 1980s and 1990s, the former outweighed the latter in 30 and 31 of the total of 34 real price indices considered, respectively. In the 1960s, the equivalent figure was 19; and in the 1970s and 2000s, seven and one, respectively. In the period 1970-2009, the net falls or increases in commodity prices seem to be highly correlated; in other words, they experienced net falls or net increases jointly. This is consistent with the fourth stylized fact mentioned in section II, and also with what can be inferred from the database used here. ${ }^{11}$

\section{(b) Results for the decade of 2000}

The real commodity-price indices in this decade had the following features:

(i) In this sample, all commodities and their groupings, except for tobacco, had more net price increases than net price falls.

(ii) There were more net price increases in the 2000s than in any of the four previous decades in all groupings except for oils and oilseeds. The general real price index in that decade accounted for $37 \%$ of the net price increases occurring in the entire period; the

10 The real price indices of sugar, bananas, soya meat, fish meal, copper, lead and gold were the only ones that did not fall more often than rise.

11 Most of the correlations between aggregate price indices are positive; in other words, commodity prices all tend to move in the same direction. Similarly, as would be expected, the price indices of food products and agricultural raw materials are also highly correlated ( 0.85 for the whole sample); and each of these groups is highly correlated with the minerals and metals series (roughly 0.72 ). In contrast, oil displays significantly lower correlations with these three groups, owing to the dissimilar trend of the price of crude oil with respect to other commodities. 


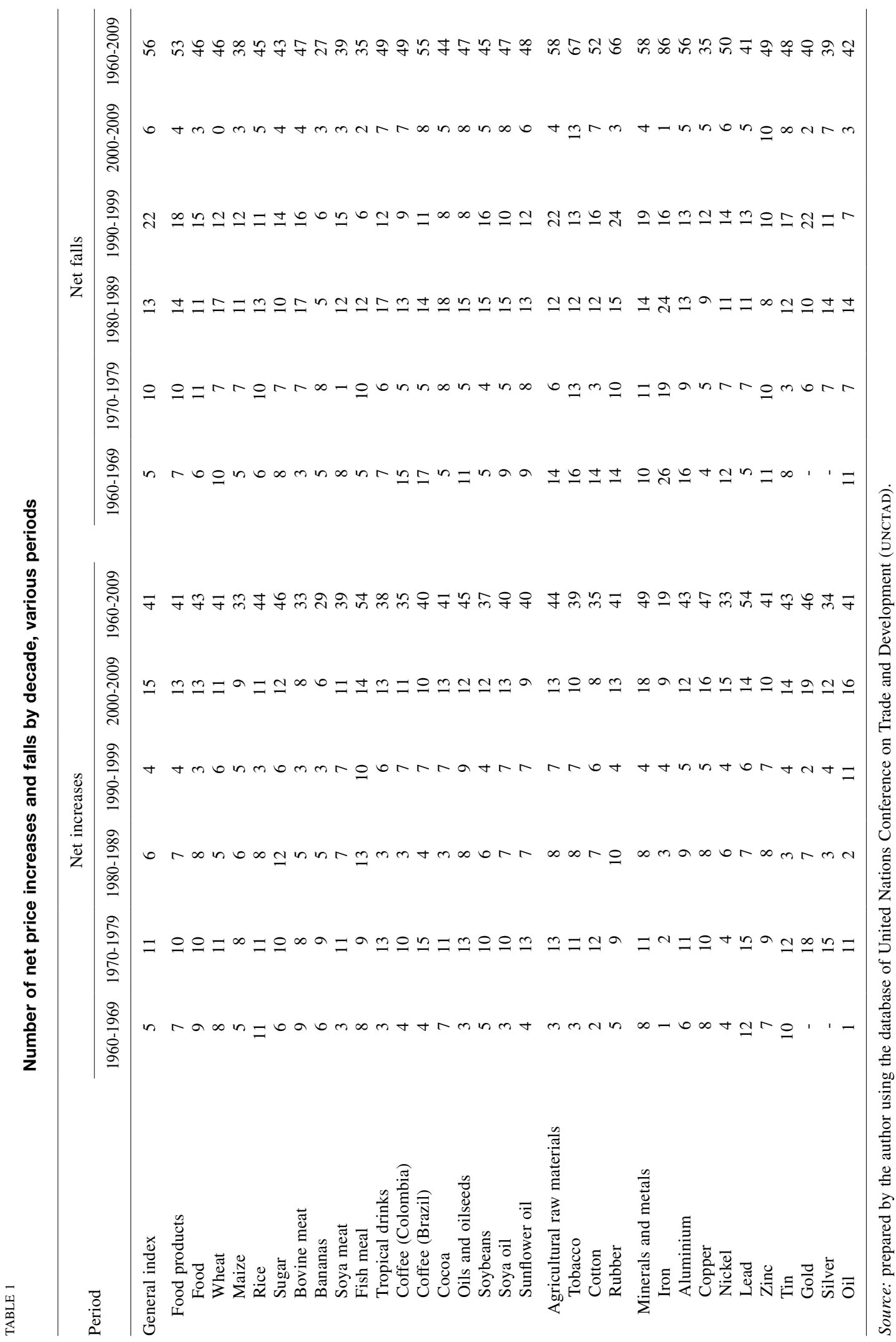


figure for the minerals and metals grouping was similar, whereas the proportion was $30 \%^{12}$ in the case of food and agricultural raw materials, and $39 \%$ in the case of oil. Clearly, the rise in commodity prices was led by minerals and metals and oil. From the standpoint of the individual indices, in 2000s, the 27 commodities in the sample recorded more net increases than in the $1980 \mathrm{~s}^{13}$ and 1990s, whereas in comparison to the 1960s and 1970s, this was true for 22 and 15 commodities, respectively.

(iii) In keeping with the above, the individual commodity indices and their groupings had fewer net price falls in this decade than in the $1990 \mathrm{~s}, 1980 \mathrm{~s},{ }^{14} 1970 \mathrm{~s}^{15}$ and $1960 \mathrm{~s}^{16}$ taken separately. Compared to the 1990 s, the number of net falls in the food product price index dropped from 18 to just four in the most recent decade, while the number of net price falls in agricultural raw materials, minerals and metals, and oil dropped from 22, 19, and 7 to just 4, 4 and 3 , respectively. In those cases, the net falls in the current decade represented less than $8 \%$ of all of those occurring since 1960 . The four commodities with the smallest proportion of total net falls were wheat (0), iron (1) and rubber and gold (5).

In the past decade, the fact that the general net increase in real commodity-price indices occurred after two decades dominated by net falls strengthens the perception that this pattern differs significantly from what happened previously, in that there were more net increases in the decade of 2000 than in each of the preceding decades for most real commodity-price indices. Nonetheless, taking the sample as a whole, what stands out most is the variability of prices: a succession of net increases followed by a period of net falls, followed in turn by a new series of net increases. This is consistent with the first stylized fact mentioned above.

\section{Commodity price cycles}

To date the cycles, this paper used a version of the Bry-Boschan algorithm —one of the most widely used

12 These proportions were $47 \%$ for iron, $46 \%$ for nickel, $41 \%$ for gold, $34 \%$ for copper, $33 \%$ for tin, and $32 \%$ for soybeans.

13 Except for sugar.

14 Except for tobacco and zinc.

15 In this case, the price indices of the groupings (tropical drinks and oils and oilseeds) and of seven individual commodities (soya meat, coffee from Colombia, coffee from Brazil, soybeans, soya oil, cotton and tin) display more net price falls in the decade of 2000 than in the 1970s.

16 Except for the general index, bovine meat and copper. methodologies. ${ }^{17}$ The same procedure was also used by Cashin, McDermott and Scott (1999a) in the case of commodity prices. ${ }^{18}$

The Bry-Boschan methodology is based firstly on detecting potential local minima and maxima, for which a three-quarter centred moving window is chosen as comparison horizon. Once the quarters have been chosen, they are subject to two additional rules: minimum duration of phases and cycles, and sequence. An upswing phase is defined as a period that starts with a minimum and ends with a maximum, whereas a fall phase is defined as a period that starts with a maximum and ends with a minimum. The series is thus described by consecutive periods of price rises and falls. A cycle encompasses two phases: rise and fall.

A price index observation for a given commodity was considered as a potential local maximum (minimum) if it represented the highest (lowest) value of the three immediately preceding and subsequent quarters. The minimum duration of a phase was defined as three quarters, which makes the minimum duration of a cycle six quarters. With regard to the sequence rule, if there are two consecutive maxima (minima), the larger (smaller) is used. ${ }^{19}$

\section{(a) Results for the whole sample}

Figure 2 exemplifies the result of applying the algorithm to the real price indices of four selected commodity groupings. In the case of the general real price index, there are six cycles and one additional upswing; in food products there are seven complete cycles, whereas agricultural raw materials display eight cycles and an upswing; and minerals and metals record seven cycles plus an upswing. For all of these groupings except for food products, the price indices cycles in the figure start

${ }^{17}$ For a detailed description of the methodology, see Bry and Boschan (1971). The version used in this article defines potential maxima and minima selection criteria, as described below, and slightly alters the algorithm to include more observations at the start and end of the sample.

18 These authors use monthly price series for 36 commodities covering the period January 1957-August 1999, and define a four-month centred moving window, encompassing the two quarters before and after each observation. The results show that during the period analysed there are six complete cycles when the different commodities are averaged, the extremes being banana and fish meal, which recorded three and 10 cycles respectively. Secondly, there is an asymmetry between price upswings and downswings in terms of duration and magnitude, in that the price falls last longer than the booms and are slightly larger in magnitude than the increases that occurred during the upswing phases.

19 This allows for the possibility of minor fall phases during an upswing and vice versa, but imposes a restriction on the length of these reversals. 
General index
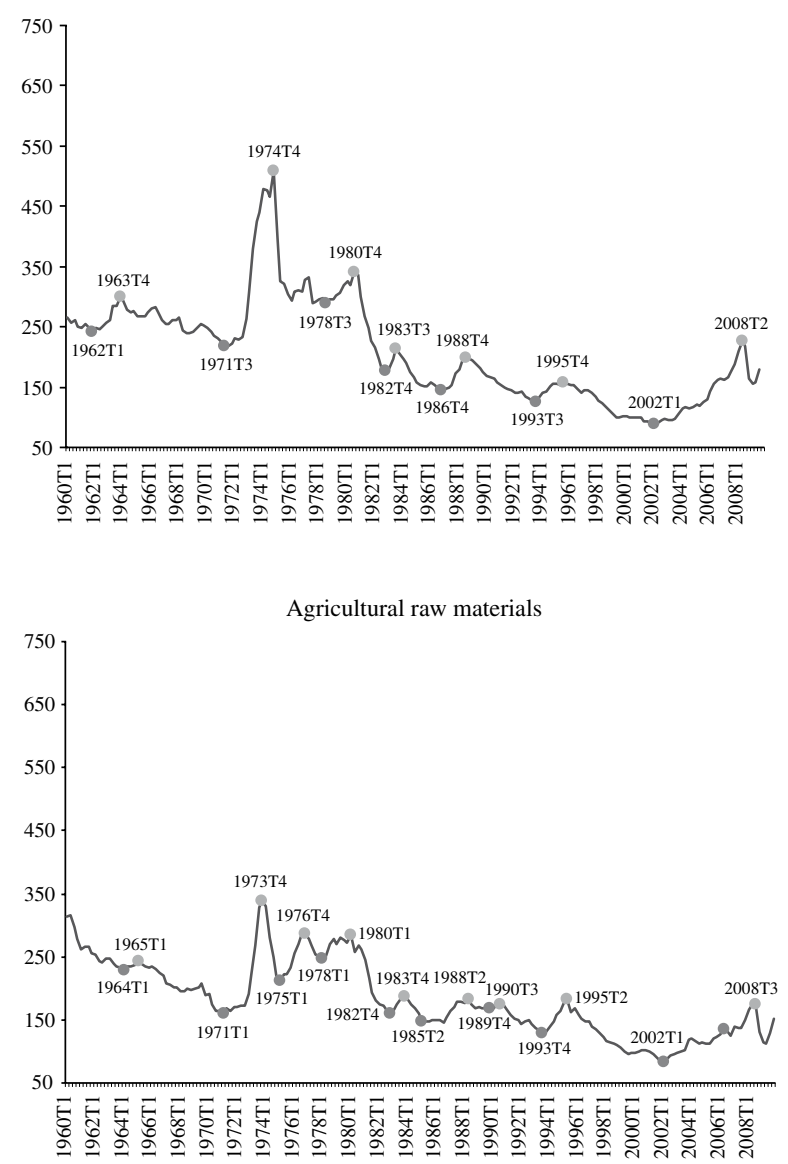

Food products
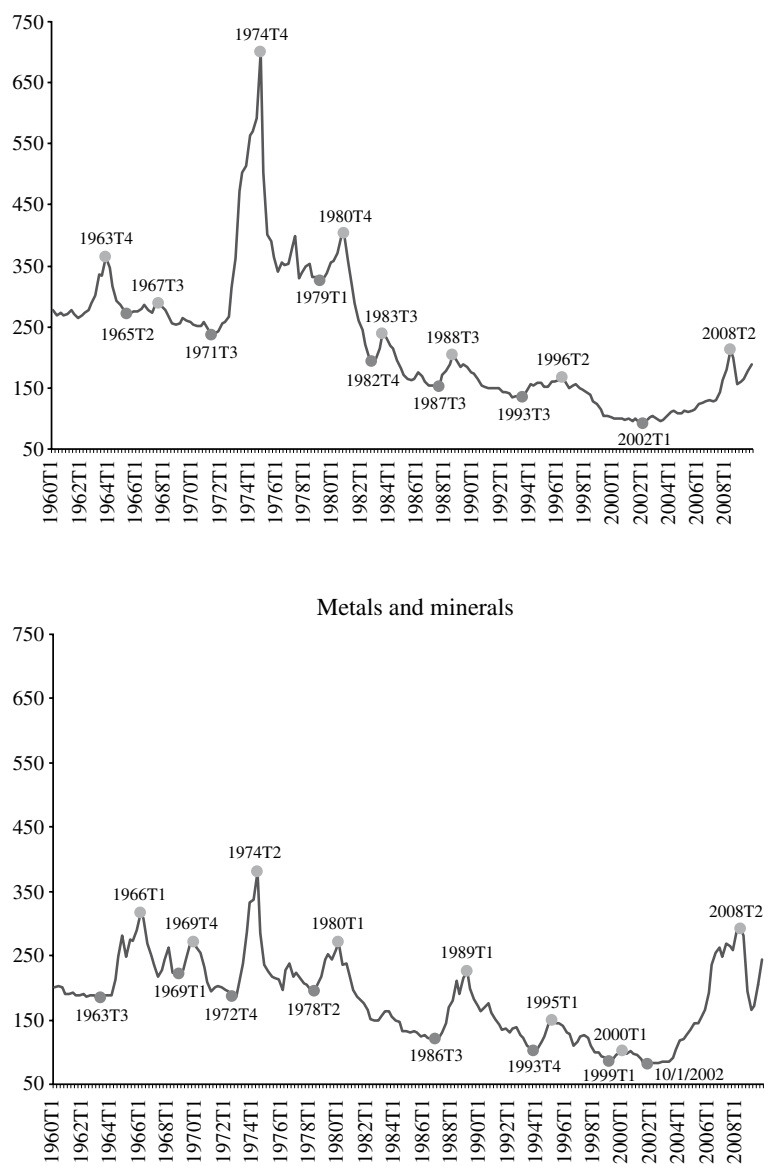

Source: prepared by the authors on the basis of data obtained from the United Nations Conference on Trade and Development (UNCTAD). Note: In these figures, the number next to the letter T indicates the quarter (trimestre) of the year in question; for example: 1969 T4 corresponds to the fourth quarter of 1969.

with an upswing. ${ }^{20}$ Figure A1.1 in annex 1 illustrates the same procedure for several selected commodities. A detailed description of the dates of the cycles and their phases, together with the variation reported in the real price index for selected commodities is shown in table A1.1. ${ }^{21}$

20 To define the cycles for each of the commodities and their groupings, the sample considered the first complete phase. As a result, for some indices, the cycles are rise-fall, whereas for others they are fall-rise. ${ }^{21}$ This information for each of the products in the sample is obtainable from the authors on request.
Table 2 shows the results of applying this algorithm to the commodity prices of the sample used. The salient points are as follows:

(i) All of the real price indices displayed multiple complete cycles ranging between three (iron and gold) and 11 (lead). Of the groupings, oils and oilseeds displayed the largest number of cycles: 10 . The real price indices of sunflower oil, cotton, copper and zinc recorded 10 cycles, whereas the general index had six complete cycles.

(ii) The average duration of the cycles varied from 16.8 quarters (lead) to 35 (iron). For the general index of prices, the average duration was 26.8 quarters. 
Commodity price cycles, rises and falls: 1960 Q1 - 2009 Q4

\begin{tabular}{|c|c|c|c|c|c|c|}
\hline & \multicolumn{2}{|r|}{ Cycles } & \multicolumn{2}{|r|}{ Rises } & \multicolumn{2}{|r|}{ Falls } \\
\hline & Number & $\begin{array}{l}\text { Average duration } \\
\text { (number of } \\
\text { quarters) }\end{array}$ & Number & $\begin{array}{l}\text { Average duration } \\
\text { (number of } \\
\text { quarters) }\end{array}$ & Number & $\begin{array}{l}\text { Average duration } \\
\text { (number of } \\
\text { quarters) }\end{array}$ \\
\hline General index & 6 & 26.8 & 7 & 10.0 & 6 & 19.3 \\
\hline Food products & 7 & 25.4 & 7 & 10.4 & 7 & 15.0 \\
\hline Food & 7 & 25.4 & 7 & 12.7 & 7 & 12.7 \\
\hline Wheat & 8 & 21.5 & 9 & 9.0 & 8 & 12.5 \\
\hline Maize & 7 & 20.9 & 8 & 9.1 & 7 & 11.7 \\
\hline Rice & 7 & 26.3 & 7 & 11.7 & 7 & 14.6 \\
\hline Sugar & 6 & 30.2 & 6 & 14.5 & 6 & 15.7 \\
\hline Beef & 7 & 22.9 & 8 & 8.1 & 8 & 14.8 \\
\hline Bananas & 9 & 18.1 & 10 & 7.7 & 9 & 10.4 \\
\hline Soya meat & 8 & 22.9 & 8 & 8.5 & 8 & 14.4 \\
\hline Fish meal & 9 & 18.2 & 9 & 10.4 & 10 & 7.8 \\
\hline Coffee (Colombia) & 7 & 22.9 & 7 & 6.0 & 7 & 16.9 \\
\hline Coffee (Brazil) & 9 & 17.1 & 9 & 5.9 & 9 & 11.2 \\
\hline Cocoa & 6 & 26.7 & 6 & 11.3 & 6 & 15.3 \\
\hline Oils and oilseeds & 10 & 17.3 & 11 & 7.7 & 10 & 9.7 \\
\hline Soybeans & 9 & 20.9 & 9 & 8.4 & 9 & 12.6 \\
\hline Soya oil & 9 & 18.7 & 10 & 7.4 & 9 & 11.2 \\
\hline Sunflower oil & 10 & 18.6 & 10 & 8.3 & 11 & 10.2 \\
\hline Agricultural raw materials & 8 & 19.0 & 9 & 9.2 & 8 & 11.9 \\
\hline Tobacco & 7 & 24.4 & 7 & 7.1 & 7 & 17.3 \\
\hline Cotton & 10 & 16.9 & 10 & 8.4 & 10 & 8.5 \\
\hline Rubber & 7 & 19.3 & 8 & 9.1 & 7 & 12.7 \\
\hline Minerals and metals & 7 & 22.0 & 8 & 9.1 & 7 & 15.3 \\
\hline Iron & 3 & 35.0 & 3 & 12.3 & 3 & 22.7 \\
\hline Aluminium & 9 & 20.2 & 10 & 8.9 & 9 & 11.3 \\
\hline Copper & 10 & 17.4 & 10 & 8.9 & 10 & 9.4 \\
\hline Nickel & 8 & 22.6 & 8 & 9.8 & 8 & 12.9 \\
\hline Tin & 8 & 21.5 & 8 & 9.4 & 8 & 12.1 \\
\hline Gold & 3 & 25.3 & 3 & 10.3 & 4 & 18.3 \\
\hline Silver & 5 & 23.8 & 6 & 10.2 & 5 & 17.0 \\
\hline Oil & 8 & 23.1 & 8 & 10.3 & 8 & 12.9 \\
\hline
\end{tabular}

Source: prepared by the authors on the basis of data obtained from the United Nations Conference on Trade and Development (UNCTAD).

(iii) For all of the commodity-price indices in the sample, except for fish meal and food products, the falls tended to last longer than the rises. ${ }^{22}$ In other words, throughout the five decades covered in the database, commodity prices were falling most of the time. On average, the falls lasted 13.5 quarters whereas the upswings lasted 9.2 quarters. In the case of the general index, the corresponding figures are 19.3 quarters and 10 quarters respectively, whereas the greatest difference in a grouping occurs in tropical drinks, where the corresponding averages with 19.5 quarters and 6.7 quarters, respectively. The real

22 This refers to rises and falls that have concluded, not those currently under way. commodity-price indices with the largest difference between the duration of falls and rises were coffee (Colombia), bovine meat, tobacco and iron.

(b) Results for the decade of 2000

The results show that, for the vast majority of commodities, the final price upswing in the 2000s is very different from those of previous periods, in terms of both duration and magnitude. All of the aggregate price series display cumulative increases of over $100 \%$ in the most important upswing of the decade; for example, the general index of all commodities posted a real increase of $158 \%$ over 20 five quarters (2002 Q1-2008 Q2). Some of the largest cumulative increases occurred in the real price indices of oil (381\%), copper 
(266\%) and silver (213\%), which spanned 26 quarters (2001 Q4-2008 Q2), 16 quarters (2002 Q3-2006 Q3) and 27 quarters (2001 Q3-2008 Q2), respectively. The largest increases occurred in oil and in commodities in the metals and minerals group. The rise in the prices of iron, copper, nickel and oil was so large that they were the only products to attain their maximum between 2007 and 2008 , as shown in table 3 .

Although these percentage increases are not very different from those observed in the 1970s for certain commodities, the key difference is in the degree of generalization and, particularly, the duration of this price-rise period. Upswings in the four previous decades lasted on average for less than seven quarters, whereas from 2002 onwards, they have averaged 14 consecutive quarters. In all aggregate indices the rising-price periods lasted 20 quarters, more than all previous periods combined. All commodities displayed this result except for the 31-quarter sugar price boom from 1967 Q1 to 1974 Q4. It should be noted that cumulative increases may be affected by the starting point of the upswing, because 16 of the 27 products recorded their 50-year minimum between 2000 and 2003 .

In terms of correlations between the price upswings of the different commodities, there is a significant joint movement encompassing oil, gold, and silver. As would be expected, the uncertainty generated by rising global energy price increases tends to push up the real prices of metals that are used as a store of value. The highest coefficients of correlation with the real oil price index are recorded by gold ( 0.75$)$ and silver $(0.70)$, whereas the correlation with the other commodities is significantly less (simple average of 0.28). Accordingly, in the 1970s, these metals also experienced two significant positive price shocks. The real price of gold rose by 3.4 times in the 13 previous quarters and up to the first oil shock (1971 Q4-1974 Q4), and then rose again over 14 quarters (1976 Q4-1980 Q1) quadrupling its real value by the end of the decade. The price of silver first rose by 3.2 times over 10 quarters (1972 Q2-1974 Q2), and then by another 5.6 times in another 10 quarter-period (1977 Q4-1980 Q1).

TABLE 3

Commodity price minima and maxima: 1960 Q1 - 2009 Q4

\begin{tabular}{|c|c|c|c|c|}
\hline & Minimum value & Date & Maximum value & Date \\
\hline General index & 88.7 & $2001 \mathrm{Q} 4$ & 503.8 & 1974 Q4 \\
\hline Food products & 92.7 & 2002 Q1 & 686.1 & 1974 Q4 \\
\hline Food & 93.3 & $2002 \mathrm{Q} 1$ & 717.1 & 1974 Q4 \\
\hline Wheat & 91.3 & 1999 Q4 & 630.1 & 1974 Q1 \\
\hline Maize & 89.2 & 2000 Q3 & 585.6 & 1974 Q4 \\
\hline Rice & 79.0 & $2001 \mathrm{Q} 2$ & 1078.3 & 1974 Q2 \\
\hline Sugar & 58.8 & 1985 Q2 & 1974.3 & 1974 Q4 \\
\hline Beef & 90.3 & 1998 Q4 & 437.3 & 1973 Q3 \\
\hline Bananas & 70.5 & 2003 Q2 & 258.8 & 1964 Q2 \\
\hline Soya meat & 82.7 & 1999 Q2 & 708.2 & 1973 Q2 \\
\hline Fish meal & 90.2 & 1999 Q2 & 567.4 & 1973 Q3 \\
\hline Tropical drinks & 72.4 & $2001 \mathrm{O} 4$ & 973.7 & 1977 Q2 \\
\hline Coffee (Colombia) & 49.8 & $2001 \mathrm{Q} 4$ & 1190.8 & 1977 Q2 \\
\hline Coffee (Brazil) & 58.2 & 2002 Q3 & 771.7 & 1977 Q2 \\
\hline Cocoa & 89.2 & $2000 \mathrm{Q} 4$ & 959.5 & 1977 Q3 \\
\hline Oils and oilseeds & 81.7 & $2001 \mathrm{Q} 2$ & 735.7 & 1974 Q4 \\
\hline Soybeans & 84.7 & $2002 \mathrm{Q} 1$ & 655.7 & 1973 Q2 \\
\hline Soya oil & 89.2 & $2000 \mathrm{Q} 4$ & 959.5 & 1974 Q4 \\
\hline Sunflower oil & 92.3 & 2000 Q4 & 984.8 & 1974 Q4 \\
\hline Agricultural raw materials & 83.4 & 2002 Q1 & 338.3 & 1973 Q4 \\
\hline Tobacco & 81.1 & $2006 \mathrm{Q} 2$ & 245.6 & 1960 Q1 \\
\hline Cotton & 63.0 & $2001 \mathrm{Q} 4$ & 491.0 & 1973 Q4 \\
\hline Rubber & 81.7 & 2001 Q4 & 1354.2 & 1960 Q2 \\
\hline Minerals and metals & 80.8 & $2001 \mathrm{Q} 4$ & 375.7 & 1974 Q2 \\
\hline Iron & 96.6 & 2002 Q1 & 408.7 & 2008 Q4 \\
\hline Aluminium & 71.6 & 2009 Q1 & 281.1 & 1988 Q2 \\
\hline Copper & 18.4 & 1961 Q1 & 352.4 & 2008 Q1 \\
\hline Nickel & 50.5 & 1998 Q4 & 435.4 & $2007 \mathrm{Q} 2$ \\
\hline Lead & 86.0 & 2003 Q1 & 484.9 & 1979 Q2 \\
\hline Zinc & 63.3 & 2003 Q1 & 509.5 & 1974 Q2 \\
\hline Tin & 68.2 & 2002 Q1 & 707.6 & 1979 Q2 \\
\hline Gold & 55.0 & 1970 Q3 & 484.6 & 1980 Q1 \\
\hline Silver & 83.8 & $2001 \mathrm{Q} 3$ & 1335.8 & 1980 Q1 \\
\hline Oil & 34.1 & 1971 Q1 & 319.2 & 2008 Q2 \\
\hline
\end{tabular}

Source: prepared by the authors on the basis of data obtained from the United Nations Conference on Trade and Development (UNCTAD). Note: The letter Q indicates the quarter of the year in question; for example 2008 Q4 refers to the fourth quarter of 2008. 


\section{IV}

\section{Persistence of real commodity-price indices}

The analysis of the persistence of the series traditionally starts with a classical unit-root test (the augmented Dickey-Fuller test or the Phillips-Perron test). If the null hypothesis of a unit root is not rejected, the series in question is considered non-stationary and therefore does not have the mean-reversion property, so any disturbance will have permanent effects. If the null hypothesis of a unit root is rejected, the series is deemed to be stationary, and the effect of the shock will be transitory. In this second case, an equation such as (1) is estimated by ordinary least squares (OLS). In this equation $P_{t}$ is the logarithm of the price index in period $t$, and $\alpha$ is the autoregressive parameter, which is used to construct measures of persistence. The closer the estimation of $\alpha$ is to 1 , the more persistent the series is considered to be. The exact configuration of the foregoing equation (in other words, inclusion of the constant term and trend) was chosen for each price series using the Akaike information criteria.

$$
P_{t}=\mu+\beta \cdot t+\alpha \cdot P_{t-1}+\varepsilon_{t}, \mu, \beta \in \Re \text { and } \alpha \in(-1,1]
$$

This procedure suffers from a number of shortcomings, however. Firstly, the unit root tests only make it possible to characterize the series as stationary or non-stationary, but do not give much information on persistence or any other characteristics. Moreover, these traditional tests of hypothesis are low-power in that they tend not to reject the null hypothesis of a unit root, so a conclusion regarding the persistence of the series might not be statistically reliable.

Secondly, estimation of the parameter $\alpha$ by oLs produces estimates that are biased towards 0 , especially when the parameter is close to 1 , since this estimator has an asymmetric distribution. ${ }^{23}$ Consequently, the present research uses the unbiased estimate of the mean (UEM) for the autoregressive parameter $\alpha$, as proposed by Andrews and Chen (1994), which makes it possible to mitigate the second problem and obtain a better estimate of the persistence of a series. ${ }^{24}$

23 See Andrews (1993).

24 For further details of the estimation see Andrews and Chen (1994).

An application to monthly commodity-price series can be found
Annex 2 shows the results of applying this persistence-evaluation procedure for the individual commodities and groupings studied in this article. To make the analysis more complete, the price indices were analysed in terms of both levels and first differences to measure the effect of a shock on commodity price levels and on their rate of variation (quarterly inflation).

Table A2.1 displays the results of the classical unitroot tests. With a confidence level of $90 \%$, the augmented Dickey-Fuller test does not reject the null hypothesis of a unit root in 20 of the series measured in terms of levels, including the general price index; in other words, the test concludes that the series are not stationary, and any shock will be permanent. For the other series, the levels test does not provide further information. At the same confidence level, the Phillips-Perron test does not reject the null hypothesis of a unit root for 29 series measured in terms of levels, also including the general index and all groupings. Lastly, both tests conclude that the rates of change of all indices are stationary, since they reject the hypothesis for all of the series when measured in terms of first differences.

The first section of table A2.2 reports estimations of the autoregressive parameter both for OLS and for UEM, for the series in terms of levels, together with two traditional measures of persistence: the cumulative impulse-response function (CIRF) and the mean life (ML) of a shock. ${ }^{25} \mathrm{As}$

in Cashin, Liang and McDermott (2000). The quantiles needed to calculate these coefficients were estimated on the basis of Monte Carlo simulations, which were based on 10,000 replicas of series with the length of the sample required in this study.

25 The CIRF measures the total cumulative effect of a unit shock over the future horizon of a series; it is calculated as the infinite sum of the impulse-response function (IRF),

$$
C I R F=\sum_{t=1}^{\infty} \operatorname{IRF}(t)=\frac{1}{1-\hat{\alpha}_{U E M}} .
$$

The ML indicates how many quarters have to elapse for half of the total effect of a price index shock to dissipate. By providing a time measure of the effect of the shock, this is a good indicator of persistence in a series. It is obtained from the expression

$$
M L=\left|\frac{\ln (0,5)}{\ln \left(\hat{\alpha}_{U E M}\right)}\right| .
$$


noted above when considering the results of the unit-root tests, the estimated coefficients of the autoregressive parameter for the equation expressed in terms of levels are very close to 1 for nearly all products. The UEM can also be seen to correct the bias of the oLs estimator, and presents estimates with higher values. According to this latter method, except for the real index of banana prices (with an estimated $\alpha$ of 0.71 ), all products have an estimated coefficient of 0.95 or higher. Accordingly, all the series in terms of levels are either stationary with very high persistence, or non-stationary. This is verified in the two persistence measures.

In the first case, the CIRF shows that the cumulative effect of a shock will be very large; for example, a shock to the price of wheat will have a total cumulative effect of 54.1 times the magnitude of the shock. With the exception of bananas, this factor has very high values and is actually infinite for many series, including the general price index and most of the groupings. In the second case, the ML shows that a shock will have lasting effects: for example, 37.1 quarters (more than nine years) would have to pass to dissipate half of the effect of the unit shock on the spot price of wheat. Here again, except for the real index of banana prices, this measure displays very high values and even is infinite in many cases.

Moreover, as can be seen from the second section of table A2.2, the estimates of the autoregressive parameter for the series in first-difference terms (rates of change) are significantly lower, although most remain statistically significant. The bias of the oLs estimator is smaller, because the values are lower, and so is the difference with respect to the UEM. The CIRF indicates that the cumulative effect of a disturbance on the rate of variation will be comparatively limited and will seldom double the magnitude of the initial shock. Lastly, the ML of the disturbance is also very low, mostly below 1 , which suggests that the effects of a shock on the rate of variation are short-lived.

In brief, the foregoing analysis shows that commodity prices are highly persistent or even non-stationary in nearly all cases; and a disturbance to the price level will have very long-lasting or permanent effects. In contrast, rates of change of prices are not very persistent, and any temporary rise in the price of a good will rapidly dissipate and have a limited impact.

The analysis demonstrated that commodity price levels are highly persistent, or even non-stationary. Nonetheless, it is possible that an autoregressive model such as (1) may fail to fully capture the persistence present in the series, and this could explain the low level of persistence shown above in the rate of change of prices. To study this feature in greater depth, an autoregressive fractionally integrated moving average (ARFIMA) $(0,1+d, 0)$ model was estimated for the price the series. This is a fractionally integrated ARMA model for the rate of change of prices, where $d$ is the integration fraction. ${ }^{26}$ This model alters equation (1) by introducing a fractional integration factor of the following type

$$
(1-L)^{1+d} \cdot P_{t}=\mu+\beta \cdot t+\varepsilon_{t}, \mu, \beta, d \in \Re
$$

The precise configuration of the foregoing equation (in other words inclusion of the constant term and trend) was chosen for each series using the Akaike information criterion. The aim now is to estimate the parameter $d$, also known as the memory parameter, which is directly related to the persistence of the series. In an ARFIMA such as (2), if $d$ is equal to 0 , the conclusion is that the variable has "short memory" and does not display any persistence. In contrast, if this parameter is within the interval $(0,0.5)$, then the series will be stationary and have the reversion-to-mean property, but it will also have "long memory". In the interval $[0.5,1)$, the variable will also be stationary, but the process no longer reverts to the mean, and the series will be of "very long memory". Lastly, for values of $d$ that are greater than or equal to 1 , the series is not stationary, and any disturbance will have permanent effects. As can be concluded, the higher the value of $d$, the longer will be the "memory" of the series, and, hence, the more persistent any disturbance.

Estimating the parameters of equation (2) is not a trivial matter, because it involves a non-linear function of the lags of the price series. This paper used several parametric and semi-parametric estimation methods, ${ }^{27}$ with results as shown in table A2.3. The values estimated by the three parametric methods are generally very similar. The results of the semi-parametric estimates show greater variability, but in most cases the differences are small. To simplify the exposition, the maximum likelihood estimator will be used in the description of

\footnotetext{
26 The number 1 in parentheses indicates first differences; in other words, as the variables are expressed in logarithms, the first difference is equivalent to the quarterly rate of variation.

27 Three parametric estimators (maximum likelihood, modified profile likelihood, and non-linear least squares) and one semiparametric estimator (the Robinson-Henry estimator) were calculated using the ARFIMA 1.04 for Ox package. Two semiparametric methods (the Geweke/Porter-Hudak estimator and the Robinson estimator) were obtained through the gphudak and roblpr extensions in the STATA software. For further details of the estimation, see the documentation of these functions.
} 
the results, although the values for the other estimators can be consulted in table A2.3.

The estimated value of $d$ for the general price index is around 0.39. This means that, although the effect of a change in the general rate of variation will be transitory, it will take a long time to dissipate because it is a "long-memory" series. In other words, the rate of inflation of the general commodity-price index displays the persistence property. For the food products group, the estimated value is 0.28 , and for its food, tropical drinks, and oils and oilseeds components, values of 0.32 , 0.26 and 0.22 were obtained, respectively. In the case of agricultural raw materials, $d$ was estimated at 0.40 , and for minerals and metals, the estimated value was 0.30 . Thus, all rates of change of prices in these groupings are persistent. Oil is the only grouping for which $d$ is not statistically different from 0 , and consequently has a "short memory".

At the individual-product level, the highest persistence is displayed by fish meal (estimated $d$ of $0.45)$, followed by aluminium (0.41), tobacco (0.34) and a zinc (0.34). In contrast, only seven products display

\section{V}

\section{Evaluation}

This study shows that, over the last five decades, the real price indices of all commodities and their groupings:

(i) Have displayed significant variability, as shown both by the presence of multiple cycles in each of the series and by the alternation of non-spurious price increases and falls.

(ii) Commodity price shocks are generally highly persistent; in other words, they take a long time to die out.

The most recent upswing period, which encompassed most commodity prices and ended between the first quarter of 2006 and the fourth quarter of 2009, differs from its predecessors in terms of its generalized nature, duration, and the fact that it was not associated with temporary supply interruptions. Moreover, its abrupt end was followed by a vigorous recovery starting in the second half of 2009. Nonetheless, these differences, in a single cycle, cannot be used to claim that a definitive change has taken place in the cyclical pattern of these series.

The expansionary phase of the latest cycle seems to have been underpinned both by real factors and by an estimated $d$ that is not significantly different from 0 , and consequently display "short memory" and low persistence: maize, bovine meat, soybeans, cotton, iron, silver and oil.

The banana price index is a special case, since the estimated value of the parameter $d$ is negative, which suggests that the variable is over-differentiated. This was also noted above, because it was the only commodity whose autoregressive coefficient was not close to 1 . When the estimation of the ARFIMA model is repeated with the series measured in terms of levels, an estimated coefficient of 0.60 is obtained that is statistically significant. ${ }^{28}$ Accordingly, the banana price series is stationary in terms of levels, but highly persistent; consequently, the rate of change of the price of this product also does not display very low persistence and could be added to the above listing.

28 In this case, the result of the estimator is reported by non-linear least squares, since it is impossible to use the maximum likelihood estimator for values of $d$ greater than 0.5 . financial ones. The former include burgeoning demand from emerging countries, such as China and India, which have become more important players in commodity markets. The financial factors include an increase in the demand for instruments such as commodity futures. Both of these factors are new on the international scene.

Since 2006, the creation and issuance of instruments indexed to commodity prices have grown significantly, with increasing participation by actors not linked to production, processing, or commercialization (mutual funds, pension funds, investment funds, commodity hedge funds in the futures markets of certain goods). Caballero, Farhi and Gourinchas (2008) argue that this interest stems from the shortage of financial assets available on international markets. Southwood (2008) estimated, for the case of copper, that about $25 \%$ of the high price prevailing in the first of 2008 reflected the activity of speculators, and the remaining $75 \%$ was underpinned by fundamental factors. This entails additional risks in commodity-price reversion processes which, by being linked to financial factors, were more abrupt and further- 
reaching than expected. In the fourth quarter of 2008, for example, the real price index of the mineral and metals, agricultural raw materials and oil groupings, posted their largest quarter-on quarter percentage fall of the last five decades: $30.6 \%, 24.9 \%$ and $50.1 \%$, respectively. ${ }^{29}$ The real price indices of aluminium and nickel fell by $32.8 \%$ and $40.7 \%$, respectively, in that quarter; while the copper price index posted its steepest ever fall of $37.5 \%$. All of this is consistent with the bursting of a price bubble.

As this paper has shown, in the latest upswing, the largest price increases were recorded in oil and products in the minerals and metals grouping. Nonetheless, oil was the only commodity to attain its all-time maximum during this upswing. In terms of sequence, the commodities whose prices reflected these increases in demand were oil and minerals and metals. The sustained increase in the price of energy products, together with a growing preference for clean energy sources, triggered growth in the biofuel industry, which meant an increase in demand for soya, wheat, maize and sugar and, hence, in their prices and those of their substitutes. ${ }^{30}$

The empirical evidence seems to reject conclusions, such as that price increases or falls are secular. ${ }^{31}$ The study has shown how, since 1960, any upswing period

29 These figures represent the seasonally adjusted quarterly growth rate.

30 From the macroeconomic standpoint, rising food prices fuelled higher inflation worldwide from late 2007 to late 2008, particularly in developing countries whose price indices are more heavily weighted in the food category. In 2009, there was a significant fall in inflation, as commodity prices revered their trend.

31 This type of work was popular in the 1980 s, because commodity prices were falling in that decade. Studies in that period tended to conclude that the decline was secular; see Reinhart and Wickham (1994). was followed by a "longer" period of price falls, which can broadly be seen in the behaviour of the different series over decades. This is consistent with the findings of studies that use longer databases; the relevant fact is not the trend of the series but its variability; in other words, price rises and falls are transitory. ${ }^{32}$ The historical experience of downward adjustments in commodity prices has been mixed in terms of the magnitude and speed of the declines. The fall in product prices in the 1980s was gradual compared to what happened in the fourth quarter of 2008.

With regard to the persistence of commodity price series, the results of this paper show that this would be a relevant factor when designing economic stabilization mechanisms, since these would tend to be unsustainable in that context. Nonetheless, the cyclical characterization of the series presented in section III shows that the series have been affected by shocks of different sign, which suggests there may be substantial room for policy to smooth out the effects of those random changes.

Lastly, the high persistence of commodity-price shocks may be one reason why they have permanent effects on the Latin American economies. Toledo (2008) found that permanent commodity-price disturbances play a significant role in productivity shocks in the Bolivarian Republic of Venezuela, Brazil, Colombia and Peru, whereas highly persistent shocks explain this result in Argentina, Chile and Mexico. One possible source of these findings could be the persistence displayed by the real commodity-price indices, in terms of levels and rates of change, which has been documented in this article.

\footnotetext{
32 Despite having lasted for several years, the recent surge in commodity prices can be considered transitory, just as, in the light of history, the "long" price declines that occurred in the 1980s also seem transitory.
} 
ANNEX 1

Identification of commodity cycles

TABLE A1.1

Commodity cycles: 1960 Q1 - 2009 Q4

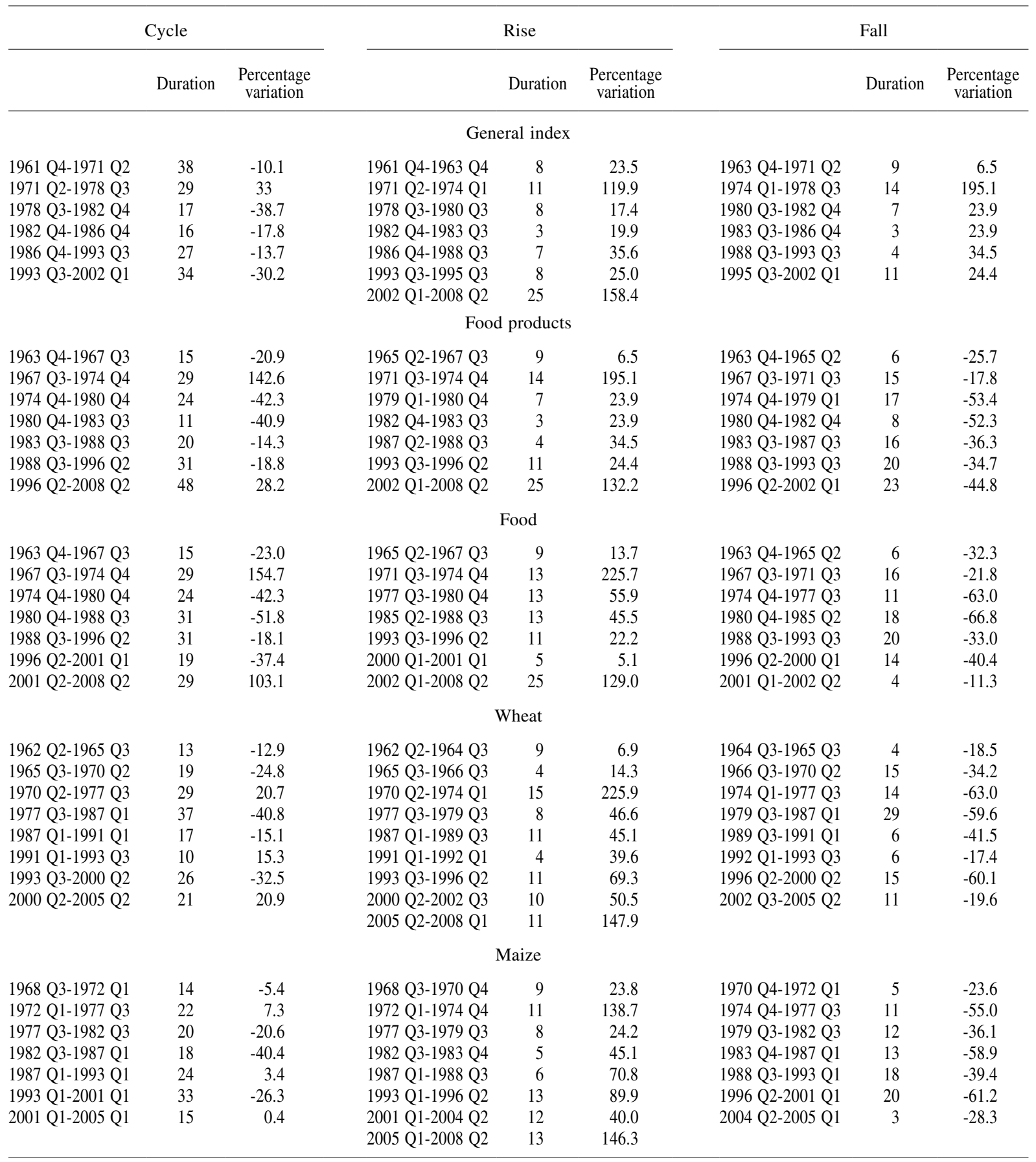


(continued)

\begin{tabular}{|c|c|c|c|c|c|}
\hline \multicolumn{2}{|l|}{ Cycle } & \multicolumn{2}{|l|}{ Rise } & \multicolumn{2}{|l|}{ Fall } \\
\hline Duration & $\begin{array}{c}\text { Percentage } \\
\text { variation }\end{array}$ & Duration & $\begin{array}{c}\text { Percentage } \\
\text { variation }\end{array}$ & Duration & $\begin{array}{c}\text { Percentage } \\
\text { variation }\end{array}$ \\
\hline
\end{tabular}

$\begin{array}{lrr}1963 \text { Q1-1968 Q2 } & 20 & 59.5 \\ 1968 \text { Q2-1971 Q4 } & 15 & 9.2 \\ 1971 \text { Q4-1975 Q1 } & 13 & -35.1 \\ \text { 1975 Q1-1977 Q2 } & 9 & 13.5 \\ \text { 1977 Q2-1986 Q3 } & 37 & -22.6 \\ \text { 1986 Q3-1998 Q4 } & 49 & -46.2 \\ 1998 \text { Q4-2002 Q4 } & 16 & 6.5 \\ \text { 2002 Q4-2008 Q4 } & 24 & -8.6\end{array}$

Beef

1962 Q3-1966 Q3 1966 Q3-1973 Q3 1973 Q3-1977 Q2 1977 Q2-1988 Q3 1988 Q3-1997 Q2 1997 Q2-2000 Q4 2000 Q4-2004 Q1 2004 Q1-2008 Q2

$\begin{array}{rr}16 & 8.1 \\ 28 & 152.9 \\ 15 & -43.9 \\ 45 & -48.6 \\ 35 & -22.2 \\ 14 & -35.3 \\ 13 & 29.8 \\ 17 & 49.7\end{array}$

1962 Q3-1969 Q2 1969 Q2-1971 Q4 1971 Q4-1975 Q2 1975 Q2-1983 Q1 1983 Q1-1993 Q2 1993 Q2-2001 Q4

$\begin{array}{lr}27 & -3.0 \\ 10 & -8.4 \\ 14 & 7.4 \\ 31 & 9.4 \\ 41 & -65.5 \\ 34 & -24.5\end{array}$

1963 Q1-1969 Q2 1969 Q2-1971 Q3 1971 Q3-1975 Q2 1975 Q2-1985 Q1 1985 Q1-1992 Q3 1992 Q3-1996 Q1 1996 Q1-2002 Q4

$\begin{array}{rr}25 & -13.6 \\ 9 & 4.3 \\ 15 & 6.0 \\ 38 & 9.3 \\ 31 & -68.8 \\ 14 & 95.1 \\ 28 & -57.2\end{array}$

$\begin{array}{lrr}1963 \text { Q2-1968 Q4 } & 22 & -4.0 \\ 1968 \text { Q4-1971 Q3 } & 11 & -0.1 \\ 1971 \text { Q3-1975 Q2 } & 15 & 30.8 \\ 1975 \text { Q2-1979 Q1 } & 15 & 41.7 \\ \text { 1979 Q1-1983 Q1 } & 16 & -26.7 \\ \text { 1983 Q1-1985 Q2 } & 9 & -7.3 \\ \text { 1985 Q2-1987 Q3 } & 9 & -34.0 \\ 1987 \text { Q3-1992 Q3 } & 20 & -59.4 \\ \text { 1992 Q3-2001 Q4 } & 37 & -33.2\end{array}$

$\begin{array}{llr}1962 \text { Q4-1969 Q2 } & 26 & -23.5 \\ 1969 \text { Q2-1972 Q3 } & 13 & 8.4 \\ 1972 \text { Q3-1976 Q2 } & 14 & 20.0 \\ 1976 \text { Q2-1982 Q4 } & 27 & -39.2 \\ 1982 \text { Q4-1986 Q3 } & 15 & -35.4\end{array}$

$\begin{array}{rr}15 & 74.3 \\ 6 & 20.7 \\ 7 & 55.1 \\ 5 & 39.9 \\ 7 & 70.3 \\ 6 & 17.2 \\ 12 & 28.2 \\ 7 & 32.6\end{array}$

Soya meat

$\begin{array}{rrr}1964 \text { Q3-1966 Q3 } & 8 & 24.7 \\ \text { 1971 Q4-1973 Q3 } & 7 & 240.3 \\ \text { 1975 Q1-1977 Q2 } & 9 & 69.9 \\ \text { 1985 Q2-1988 Q3 } & 13 & 80.6 \\ \text { 1995 Q1-1997 Q2 } & 9 & 50.4 \\ \text { 1999 Q3-2000 Q4 } & 6 & 29.0 \\ \text { 2002 Q2-2004 Q1 } & 8 & 58.1 \\ \text { 2006 Q2-2008 Q2 } & 8 & 133.4\end{array}$

Tropical drinks

$\begin{array}{rrr}1962 \text { Q3-1964 Q3 } & 8 & 22.8 \\ 1969 \text { Q2-1970 Q3 } & 4 & 13.2 \\ 1971 \text { Q4-1974 Q2 } & 10 & 53.4 \\ 1975 \text { Q2-1977 Q3 } & 8 & 282.8 \\ 1983 \text { Q1-1984 Q2 } & 5 & 21.6 \\ 1993 \text { Q2-1994 Q3 } & 5 & 160.4\end{array}$

Coffee (Colombia)

$\begin{array}{llr}1963 \text { Q1-1964 Q3 } & 6 & 27.1 \\ 1969 \text { Q2-1970 Q2 } & 4 & 36.3 \\ 1971 \text { Q3-1973 Q1 } & 6 & 45.2 \\ 1975 \text { Q2-1977 Q2 } & 8 & 278.8 \\ 1985 \text { Q1-1986 Q1 } & 5 & 69.9 \\ 1992 \text { Q3-1994 Q3 } & 8 & 245.8 \\ 1996 \text { Q1-1997 Q2 } & 5 & 78.7\end{array}$

Coffee (Brazil)

1963 Q2-1964 Q2 $4 \quad 40.5$

1968 Q4-1970 Q3 $7 \quad 42.1$

1971 Q3-1973 Q4 $9 \quad 58.4$

1975 Q2-1977 Q2 8304.7

1979 Q1-1979 Q4 $3 \quad 47.2$

1983 Q1-1984 Q3

1985 Q2-1986 Q1

1987 Q3-1988 Q4

1992 Q3-1994 Q3
47.2
6.0

92.7

24.1

312.3
1966 Q4-1968 Q2

1969 Q3-1971 Q4

1973 Q3-1975 Q1

1976 Q2-1977 Q2

1979 Q1-1986 Q3

1988 Q1-1998 Q4

2001 Q4-2002 Q4

2004 Q3-2008 Q4

1962 Q3-1964 Q3

1966 Q3-1971 Q4

1973 Q3-1975 Q1

1977 Q2-1985 Q2

1988 Q3-1995 Q1

1997 Q2-1999 Q3

2000 Q4-2002 Q2

2004 Q1-2006 Q2
$-8.5$

$-9.5$

$-58.2$

$-18.9$

$-54.5$

$-54.1$

$-16.9$

$-17.6$

Oils and oilseeds

$\begin{array}{lrr}1962 \text { Q4-1965 Q2 } & 10 & 28.3 \\ 1969 \text { Q2-1970 Q4 } & 6 & 38.8 \\ 1972 \text { Q3-1974 Q4 } & 9 & 173.0 \\ 1976 \text { Q2-1979 Q2 } & 13 & 40.8 \\ 1982 \text { Q4-1984 Q2 } & 6 & 88.1\end{array}$

1965 Q2-1969 Q2 1970 Q4-1972 Q3 1974 Q4-1976 Q2 1979 Q2-1982 Q4 1984 Q2-1986 Q3

1964 Q3-1969 Q2 1970 Q2-1971 Q4 1974 Q2-1975 Q2 1977 Q2-1983 Q1 1984 Q3-1993 Q2 1994 Q3-2001 Q4

$-21.0$

$-19.1$

$-30.0$

$-71.4$

$-71.6$

$-71.0$

1964 Q3-1969 Q2 1970 Q2-1971 Q3 1973 Q1-1975 Q2 1977 Q2-1985 Q1 1986 Q1-1992 Q3 1994 Q3-1996 Q1 1997 Q2-2002 Q4

$-32.1$ $-23.5$ $-27.0$

$-71.1$ $-81.6$ $-43.6$ $-76.1$

1964 Q2-1968 Q4 1970 Q3-1971 Q3 1973 Q4-1975 Q2 1977 Q2-1979 Q1 1979 Q4-1983 Q1 1984 Q3-1985 Q2 1986 Q1-1987 Q3 1988 Q4-1992 Q3 1994 Q3-2001 Q4 


\begin{tabular}{|c|c|c|c|c|c|c|c|c|}
\hline \multicolumn{3}{|c|}{ Cycle } & \multicolumn{3}{|c|}{ Rise } & \multicolumn{3}{|c|}{ Fall } \\
\hline & Duration & $\begin{array}{l}\text { Percentage } \\
\text { variation }\end{array}$ & & Duration & $\begin{array}{l}\text { Percentage } \\
\text { variation }\end{array}$ & & Duration & $\begin{array}{l}\text { Percentage } \\
\text { variation }\end{array}$ \\
\hline \multicolumn{9}{|c|}{ Oils and oilseeds } \\
\hline 1993 Q2-1997 Q4 & 17 & 15.3 & 1993 Q2-1995 Q1 & 6 & 38.7 & 1995 Q1-1997 Q4 & 11 & -16.8 \\
\hline 2001 Q1-2006 Q2 & 19 & 42.7 & 2001 Q1-2004 Q1 & 11 & 95.0 & 2004 Q1-2006 Q2 & 8 & -26.8 \\
\hline & & & 2006 Q2-2008 Q2 & 9 & 139.8 & & & \\
\hline \multicolumn{9}{|c|}{ Soya } \\
\hline 1961 Q2-1966 Q3 & 21 & 7.7 & 1962 Q1-1966 Q3 & 18 & 31.4 & 1961 Q2-1962 Q1 & 3 & -18.1 \\
\hline 1966 Q3-1973 Q2 & 27 & 90.2 & 1969 Q3-1973 Q2 & 15 & 195.3 & 1966 Q3-1969 Q3 & 12 & -35.6 \\
\hline 1973 Q2-1977 Q2 & 16 & -28.9 & 1976 Q1-1977 Q2 & 5 & 65.8 & 1973 Q2-1976 Q1 & 11 & -57.1 \\
\hline 1983 Q4-1988 Q3 & 19 & -9.5 & 1987 Q3-1988 Q3 & 6 & 61.2 & 1983 Q4-1987 Q2 & 13 & -43.8 \\
\hline 1988 Q3-1993 Q3 & 20 & -33.8 & 1992 Q3-1993 Q3 & 3 & 18.4 & 1988 Q3-1992 Q3 & 17 & -44.1 \\
\hline 1993 Q3-1996 Q3 & 12 & 7.6 & 1994 Q4-1996 Q3 & 7 & 30.4 & 1993 Q3-1994 Q4 & 5 & -17.5 \\
\hline 1996 Q3-2004 Q1 & 30 & -5.0 & 2002 Q1-2004 Q1 & 8 & 89.0 & 1996 Q3-2002 Q1 & 22 & -49.7 \\
\hline 2004 Q1-2008 Q3 & 17 & 36.3 & 2006 Q1-2008 Q3 & 10 & 111.7 & 2004 Q1-2006 Q1 & 8 & -36.2 \\
\hline \multicolumn{9}{|c|}{ Soya oil } \\
\hline 1964 Q1-1969 Q2 & 21 & -30.3 & 1964 Q1-1965 Q1 & 4 & 41.9 & 1965 Q1-1969 Q2 & 17 & -50.9 \\
\hline 1969 Q2-1972 Q3 & 13 & 15.9 & 1969 Q2-1971 Q3 & 9 & 68.1 & 1971 Q3-1972 Q3 & 4 & -31.1 \\
\hline 1972 Q3-1976 Q1 & 14 & 28.8 & 1972 Q3-1974 Q4 & 9 & 253.9 & 1974 Q4-1976 Q1 & 5 & -63.6 \\
\hline 1976 Q1-1983 Q1 & 28 & -40.5 & 1976 Q1-1977 Q2 & 5 & 72.7 & 1977 Q2-1983 Q1 & 23 & -65.5 \\
\hline 1983 Q1-1986 Q3 & 14 & -32.2 & 1983 Q1-1984 Q2 & 5 & 91.2 & 1984 Q2-1986 Q3 & 9 & -64.5 \\
\hline 1986 Q3-1992 Q4 & 25 & 4.4 & 1986 Q3-1988 Q3 & 8 & 63.8 & 1988 Q3-1992 Q4 & 17 & -36.3 \\
\hline 1992 Q4-1996 Q4 & 16 & 11.7 & 1992 Q4-1994 Q4 & 8 & 54.5 & 1994 Q4-1996 Q4 & 8 & -27.7 \\
\hline 1996 Q4-2001 Q1 & 16 & -46.1 & 1996 Q4-1998 Q2 & 6 & 24.8 & 1998 Q2-2001 Q1 & 10 & -56.8 \\
\hline 2001 Q1-2006 Q1 & 21 & 53.3 & 2001 Q1-2004 Q1 & 13 & 113.0 & 2004 Q1-2006 Q1 & 8 & -28.0 \\
\hline \multicolumn{9}{|c|}{ Agricultural raw materials } \\
\hline 1964 Q1-1971 Q1 & 28 & -29.9 & 1964 Q1-1965 Q1 & 4 & 6.0 & 1965 Q1-1971 Q1 & 24 & -33.9 \\
\hline 1971 Q1-1975 Q1 & 16 & 32.4 & 1971 Q1-1973 Q4 & 11 & 111.1 & 1973 Q4-1975 Q1 & 5 & -37.3 \\
\hline 1975 Q1-1978 Q1 & 12 & 16.1 & 1975 Q1-1976 Q4 & 7 & 34.4 & 1976 Q4-1978 Q1 & 5 & -13.7 \\
\hline 1978 Q1-1982 Q4 & 19 & -34.8 & 1978 Q1-1980 Q1 & 8 & 15.3 & 1980 Q1-1982 Q4 & 11 & -43.5 \\
\hline 1982 Q4-1985 Q2 & 9 & -8.9 & 1982 Q4-1983 Q4 & 4 & 15.9 & 1983 Q4-1985 Q2 & 5 & -21.4 \\
\hline 1985 Q2-1989 Q4 & 19 & 14.2 & 1985 Q2-1988 Q2 & 13 & 24.9 & 1988 Q2-1989 Q4 & 6 & -8.6 \\
\hline 1989 Q4-1993 Q4 & 15 & -23.1 & 1989 Q4-1990 Q3 & 3 & 3.9 & 1990 Q3-1993 Q4 & 12 & -26.0 \\
\hline 1993 Q4-2002 Q1 & 34 & -35.4 & 1993 Q4-1995 Q2 & 7 & 41.3 & 1995 Q2-2002 Q1 & 27 & -54.2 \\
\hline 2002 Q1 & & & 2002 Q1-2008 Q3 & 26 & 109.7 & & & \\
\hline \multicolumn{9}{|c|}{ Tobacco } \\
\hline 1963 Q3-1973 Q2 & 38 & -25.5 & 1963 Q3-1966 Q1 & 10 & 26.5 & 1966 Q1-1973 Q2 & 28 & -41.1 \\
\hline 1973 Q2-1981 Q3 & 34 & 1.6 & 1973 Q2-1976 Q4 & 15 & 62.9 & 1976 Q4-1981 Q3 & 19 & -37.6 \\
\hline 1981 Q3-1984 Q1 & 10 & 3.3 & 1981 Q3-1984 Q2 & 3 & 9.9 & 1984 Q2-1984 Q1 & 7 & -6.0 \\
\hline 1984 Q1-1985 Q4 & 7 & -10.6 & 1984 Q1-1984 Q4 & 3 & 7.2 & 1984 Q4-1985 Q4 & 4 & -16.6 \\
\hline 1985 Q4-1988 Q2 & 10 & -12.7 & 1985 Q4-1986 Q4 & 4 & 8.3 & 1986 Q4-1988 Q2 & 6 & -19.4 \\
\hline 1988 Q2-1995 Q2 & 28 & -17.3 & 1988 Q2-1989 Q4 & 6 & 31.6 & 1989 Q4-1995 Q2 & 22 & -37.1 \\
\hline 1995 Q2-2006 Q2 & 44 & -15.19 & 1995 Q2-1997 Q3 & 9 & 35.5 & 1997 Q3-2006 Q2 & 35 & -37.4 \\
\hline \multicolumn{9}{|c|}{ Minerals and metals } \\
\hline 1963 Q3-1969 Q1 & 22 & 19.7 & 1963 Q3-1966 Q1 & 11 & 71.9 & 1966 Q1-1969 Q1 & 11 & -30.4 \\
\hline 1969 Q1-1972 Q4 & 15 & -15.6 & 1969 Q1-1969 Q4 & 4 & 23.1 & 1964 Q4-1972 Q4 & 11 & -31.4 \\
\hline 1972 Q4-1978 Q2 & 23 & 4.9 & 1972 Q4-1974 Q2 & 7 & 104.8 & 1974 Q2-1978 Q2 & 16 & -48.8 \\
\hline 1978 Q2-1986 Q3 & 34 & -38.9 & 1978 Q2-1980 Q1 & 7 & 38.8 & 1980 Q1-1986 Q3 & 27 & -56.0 \\
\hline 1986 Q3-1993 Q4 & 28 & -15.5 & 1986 Q3-1986 Q1 & 9 & 88.4 & 1989 Q1-1993 Q4 & 19 & -55.1 \\
\hline 1993 Q4-1999 Q1 & 21 & -15.7 & 1993 Q4-1995 Q1 & 5 & 48.5 & 1995 Q1-1999 Q1 & 16 & -43.2 \\
\hline \multirow[t]{2}{*}{1999 Q1-2002 Q4 } & 11 & -4.4 & 1999 Q1-2000 Q1 & 4 & 18.7 & 2000 Q1-2002 Q4 & 7 & -19.4 \\
\hline & & & 2002 Q4-2008 Q2 & 26 & 259.3 & & & \\
\hline
\end{tabular}




\begin{tabular}{|c|c|c|c|c|c|c|c|c|}
\hline \multicolumn{3}{|c|}{ Cycle } & \multicolumn{3}{|c|}{ Rise } & \multicolumn{3}{|c|}{ Fall } \\
\hline & Duration & $\begin{array}{l}\text { Percentage } \\
\text { variation }\end{array}$ & & Duration & $\begin{array}{l}\text { Percentage } \\
\text { variation }\end{array}$ & & Duration & $\begin{array}{c}\text { Percentage } \\
\text { variation }\end{array}$ \\
\hline \multicolumn{9}{|c|}{ Iron } \\
\hline 1973 Q3-1988 Q4 & 60 & -11.9 & 1973 Q3-1975 Q2 & 6 & 103.5 & 1975 Q2-1988 Q4 & 54 & -56.7 \\
\hline 1988 Q4-1994 Q2 & 21 & -13.6 & 1988 Q4-1991 Q4 & 12 & 23.8 & 1991 Q4-1994 Q2 & 9 & -30.2 \\
\hline 1994 Q2-2000 Q1 & 24 & -6.4 & 1994 Q2-1998 Q4 & 19 & 6.9 & 1998 Q4-2000 Q1 & 5 & -12.4 \\
\hline \multicolumn{9}{|c|}{ Copper } \\
\hline 1963 Q2-1967 Q2 & 16 & 47.2 & 1963 Q2-1966 Q1 & 11 & 167.6 & 1966 Q1-1967 Q2 & 5 & -45.0 \\
\hline 1967 Q2-1972 Q2 & 20 & -9.0 & 1967 Q2-1969 Q4 & 10 & 73.6 & 1969 Q4-1972 Q2 & 10 & -47.5 \\
\hline 1972 Q2-1975 Q2 & 12 & 0.9 & 1972 Q2-1974 Q2 & 8 & 136.9 & 1974 Q2-1975 Q2 & 4 & -57.4 \\
\hline 1975 Q2-1978 Q1 & 11 & 4.3 & 1975 Q2-1976 Q3 & 5 & 54.8 & 1976 Q3-1978 Q1 & 6 & -32.6 \\
\hline 1978 Q1-1982 Q3 & 17 & -17.7 & 1978 Q1-1980 Q1 & 8 & 35.9 & 1980 Q1-1982 Q3 & 9 & -39.5 \\
\hline 1982 Q3-1987 Q1 & 19 & -6.3 & 1982 Q3-1985 Q1 & 11 & 34.5 & 1985 Q1-1987 Q1 & 8 & -30.3 \\
\hline 1987 Q1-1993 Q4 & 27 & -0.8 & 1987 Q1-1989 Q1 & 8 & 96.9 & 1987 Q1-1993 Q4 & 19 & -49.6 \\
\hline 1993 Q4-1999 Q1 & 21 & -33.2 & 1993 Q4-1995 Q1 & 5 & 59.4 & 1995 Q1-1999 Q1 & 16 & -58.1 \\
\hline 1999 Q1-2002 Q3 & 14 & 4.5 & 1999 Q1-2000 Q4 & 7 & 39.6 & 2000 Q4-2002 Q3 & 7 & -25.2 \\
\hline 2002 Q3-2009 Q1 & 26 & & 2002 Q3-2006 Q3 & 16 & 255.6 & 2006 Q3-2009 Q1 & 10 & -42.1 \\
\hline \multicolumn{9}{|c|}{ Nickel } \\
\hline 1962 Q1-1970 Q1 & 32 & 23.9 & 1966 Q1-1970 Q1 & 16 & -8.6 & 1962 Q1-1966 Q1 & 16 & 35.5 \\
\hline 1970 Q1-1974 Q4 & 18 & 13.8 & 1972 Q2-1974 Q4 & 8 & -6.5 & 1970 Q1-1972 Q2 & 10 & 21.7 \\
\hline 1974 Q4-1979 Q4 & 21 & 2.4 & 1978 Q4-1979 Q4 & 17 & -26.1 & 1974 Q4-1978 Q4 & 4 & 38.5 \\
\hline 1979 Q4-1983 Q4 & 15 & -41.6 & 1983 Q1-1983 Q4 & 12 & -51.0 & 1979 Q4-1983 Q1 & 3 & 19.1 \\
\hline 1983 Q4-1989 Q1 & 22 & 204.0 & 1986 Q4-1989 Q1 & 13 & -29.0 & 1983 Q4-1986 Q4 & 9 & 328.3 \\
\hline 1989 Q1-1995 Q3 & 26 & -60.6 & 1993 Q4-1995 Q3 & 18 & -77.9 & 1989 Q1-1993 Q4 & 8 & 78.3 \\
\hline $1995 \mathrm{Q} 3-2000 \mathrm{Q} 2$ & 19 & -9.7 & 1998 Q4-2000 Q2 & 13 & -57.0 & 1995 Q3-1998 Q4 & 6 & 110.1 \\
\hline 2000 Q2-2007 Q2 & 28 & 311.1 & 2001 Q4-2007 Q2 & 6 & -44.5 & 2000 Q2-2001 Q4 & 22 & 641.1 \\
\hline \multicolumn{9}{|c|}{ Zinc } \\
\hline 1962 Q3-1968 Q4 & 25 & 24.0 & 1962 Q3-1964 Q3 & 8 & 91.2 & 1964 Q3-1968 Q4 & 17 & -35.1 \\
\hline 1968 Q4-1971 Q1 & 9 & -5.0 & 1968 Q4-1969 Q4 & 4 & 8.4 & 1969 Q4-1971 Q1 & 5 & -12.3 \\
\hline 1971 Q1-1978 Q1 & 28 & 14.7 & 1971 Q1-1974 Q2 & 13 & 375.3 & 1974 Q2-1978 Q1 & 15 & -75.9 \\
\hline 1978 Q1-1983 Q1 & 20 & -15.8 & 1978 Q1-1979 Q1 & 4 & 38.6 & 1979 Q1-1983 Q1 & 16 & -39.2 \\
\hline 1983 Q1-1986 Q2 & 12 & -18.4 & 1983 Q1-1984 Q1 & 4 & 43.1 & 1984 Q1-1986 Q2 & 8 & -42.9 \\
\hline 1986 Q2-1993 Q3 & 30 & 11.8 & 1986 Q2-1989 Q1 & 12 & 197.8 & 1989 Q1-1993 Q3 & 18 & -62.4 \\
\hline 1993 Q3-1996 Q3 & 12 & 3.6 & 1993 Q3-1994 Q4 & 5 & 18.8 & 1994 Q4-1996 Q3 & 7 & -12.8 \\
\hline 1996 Q3-1999 Q1 & 9 & -8.7 & 1996 Q3-1997 Q3 & 4 & 55.8 & 1997 Q3-1999 Q1 & 5 & -41.4 \\
\hline 1999 Q1-2003 Q1 & 17 & -29.8 & 1999 Q1-1999 Q4 & 4 & 21.4 & 1999 Q4-2003 Q1 & 13 & -42.2 \\
\hline 2003 Q1-2009 Q1 & 24 & 34.7 & 2003 Q1-2006 Q4 & 15 & 424.0 & 2006 Q4-2009 Q1 & 9 & -74.3 \\
\hline \multicolumn{9}{|c|}{ Tin } \\
\hline 1965 Q2-1970 Q1 & 19 & -23.4 & 1968 Q3-1970 Q1 & 6 & 12.7 & 1965 Q2-1968 Q3 & 13 & -32.0 \\
\hline 1970 Q1-1974 Q2 & 17 & 86.2 & 1971 Q3-1974 Q2 & 11 & 116.7 & 1970 Q1-1971 Q3 & 6 & -14.0 \\
\hline 1974 Q2-1979 Q2 & 20 & 19.9 & 1975 Q4-1979 Q2 & 14 & 94.8 & 1974 Q2-1975 Q4 & 6 & -38.4 \\
\hline 1979 Q2-1989 Q2 & 40 & -63.5 & 1986 Q3-1989 Q2 & 11 & 61.5 & 1979 Q2-1986 Q3 & 29 & -77.4 \\
\hline 1989 Q2-1992 Q3 & 13 & -41.2 & 1991 Q3-1992 Q3 & 5 & 17.6 & 1989 Q2-1991 Q3 & 8 & -50.1 \\
\hline 1992 Q3-1995 Q3 & 12 & -9.4 & 1993 Q3-1995 Q3 & 8 & 32.2 & 1992 Q3-1993 Q3 & 4 & -31.4 \\
\hline 1995 Q3-2004 Q3 & 36 & 12.7 & 2002 Q1-2004 Q3 & 10 & 127.5 & 1995 Q3-2002 Q1 & 26 & -50.5 \\
\hline 2004 Q3-2008 Q2 & 15 & 106.7 & 2005 Q4-2008 Q2 & 10 & 202.7 & 2004 Q3-2005 Q4 & 5 & -31.7 \\
\hline \multicolumn{9}{|c|}{ Gold } \\
\hline 1975 Q1-1980 Q1 & 22 & 128.0 & 1976 Q3-1980 Q1 & 16 & 285.2 & 1975 Q1-1976 Q3 & 6 & -40.8 \\
\hline 1980 Q1-1987 Q4 & 29 & -47.3 & 1985 Q1-1987 Q4 & 11 & 39.3 & 1980 Q1-1985 Q1 & 18 & -62.2 \\
\hline 1987 Q4-1994 Q1 & 25 & -35.1 & 1993 Q1-1994 Q1 & 4 & 13.9 & 1987 Q4-1993 Q1 & 21 & -43.0 \\
\hline 1994 Q1 & & & & & & 1994 Q1-2001 Q1 & 28 & -44.2 \\
\hline
\end{tabular}


(concluded)

\begin{tabular}{|c|c|c|c|c|c|c|c|c|}
\hline \multicolumn{3}{|c|}{ Cycle } & \multicolumn{3}{|c|}{ Rise } & \multicolumn{3}{|c|}{ Fall } \\
\hline & Duration & $\begin{array}{l}\text { Percentage } \\
\text { variation }\end{array}$ & & Duration & $\begin{array}{l}\text { Percentage } \\
\text { variation }\end{array}$ & & Duration & $\begin{array}{l}\text { Percentage } \\
\text { variation }\end{array}$ \\
\hline \multicolumn{9}{|c|}{ Silver } \\
\hline 1971 Q4-1977 Q3 & 23 & 114.3 & 1971 Q4-1974 Q2 & 10 & 205.5 & 1974 Q2-1977 Q3 & 13 & -29.9 \\
\hline 1977 Q3-1982 Q2 & 19 & -3.1 & 1977 Q3-1980 Q1 & 10 & 444.1 & 1980 Q1-1982 Q2 & 9 & -82.2 \\
\hline 1982 Q2-1986 Q2 & 16 & -33.2 & 1982 Q2-1983 Q2 & 4 & 77.3 & 1983 Q2-1986 Q2 & 12 & -62.3 \\
\hline 1986 Q2-1993 Q1 & 27 & -44.7 & 1986 Q2-1987 Q2 & 4 & 44.9 & 1987 Q2-1993 Q1 & 23 & -61.9 \\
\hline 1993 Q1-2001 Q3 & 34 & -6.6 & 1993 Q1-1994 Q3 & 6 & 38.9 & 1994 Q3-2001 Q3 & 28 & -32.8 \\
\hline & & & 2001 Q3-2008 Q2 & 27 & 212.9 & & & \\
\hline \multicolumn{9}{|c|}{ Oil } \\
\hline 1962 Q1-1974 Q1 & 48 & 259.0 & 1971 Q4-1974 Q1 & 13 & 383.1 & 1962 Q1-1971 Q4 & 35 & -25.7 \\
\hline 1974 Q1-1977 Q1 & 12 & -18.7 & 1975 Q4-1977 Q1 & 5 & 15.1 & 1974 Q1-1975 Q4 & 7 & -29.3 \\
\hline 1977 Q1-1979 Q4 & 11 & 122.7 & 1978 Q2-1979 Q4 & 6 & 152.9 & 1977 Q1-1978 Q2 & 5 & -12.0 \\
\hline 1979 Q4-1987 Q3 & 31 & -66.8 & 1986 Q3-1987 Q3 & 5 & 44.6 & 1979 Q4-1986 Q3 & 26 & -77.1 \\
\hline 1987 Q3-1990 Q4 & 13 & 37.8 & 1988 Q4-1990 Q4 & 8 & 112.4 & 1987 Q3-1988 Q4 & 5 & -35.1 \\
\hline 1990 Q4-1996 Q4 & 24 & -34.5 & 1994 Q1-1996 Q4 & 11 & 56.1 & 1990 Q4-1994 Q1 & 13 & -58.0 \\
\hline 1996 Q4-2000 Q4 & 16 & 18.9 & 1998 Q4-2000 Q4 & 8 & 151.7 & 1996 Q4-1998 Q4 & 8 & -52.8 \\
\hline 2000 Q4-2008 Q2 & 30 & 212.5 & 2001 Q4-2008 Q2 & 26 & 380.6 & 2000 Q4-2001 Q1 & 4 & -35.0 \\
\hline
\end{tabular}

Source: prepared by the authors on the basis of data obtained from the United Nations Conference on Trade and Development (UNCTAD). Note: The number next to the letter Q indicates the quarter of the year; for example: 2008 Q4 corresponds to the fourth quarter. 
FIGURE A1.1

Cycles of real price indices: Selected products 1960 Q1 - 2009 Q4

(Base year 2000=100)
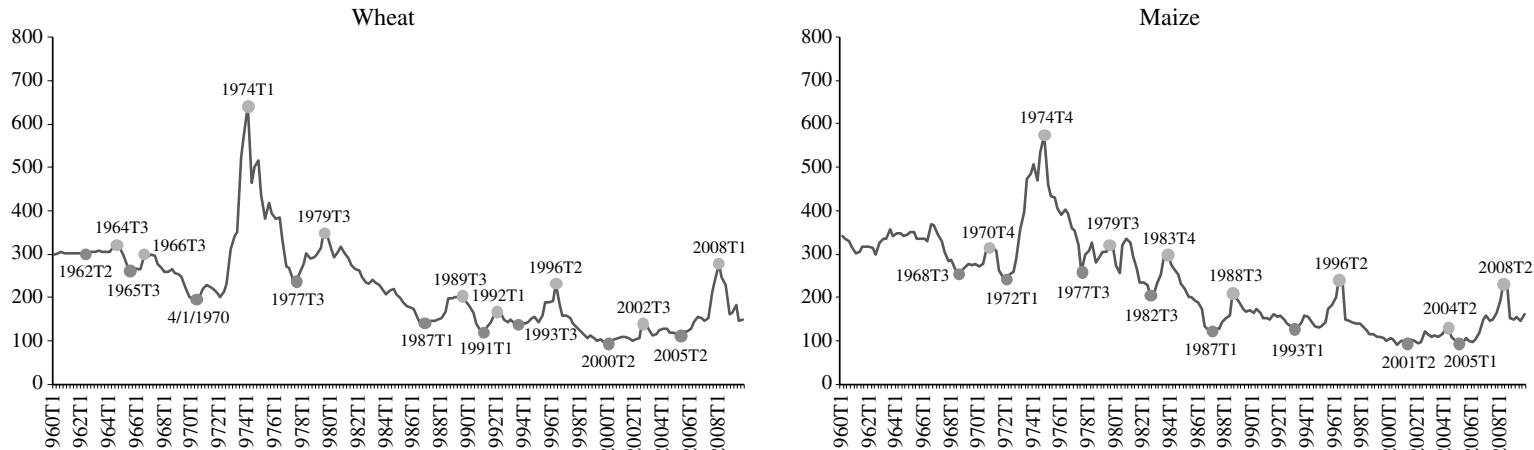

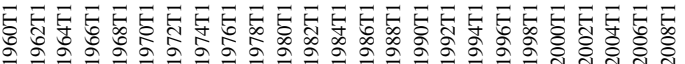
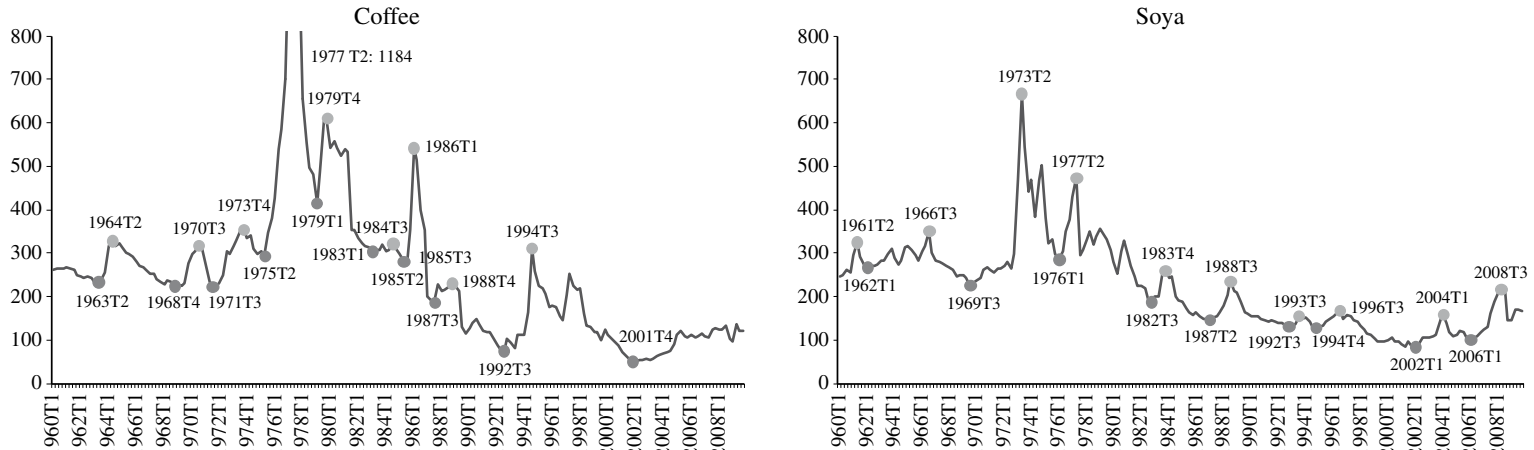

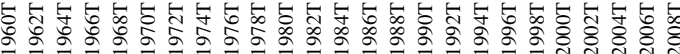

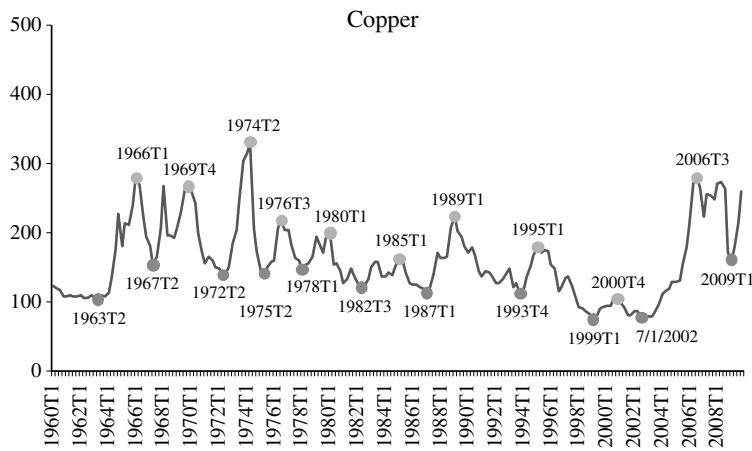

Tin

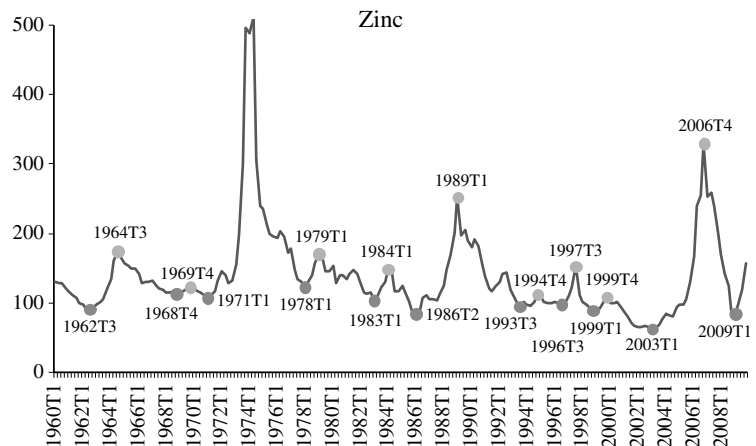

Oil
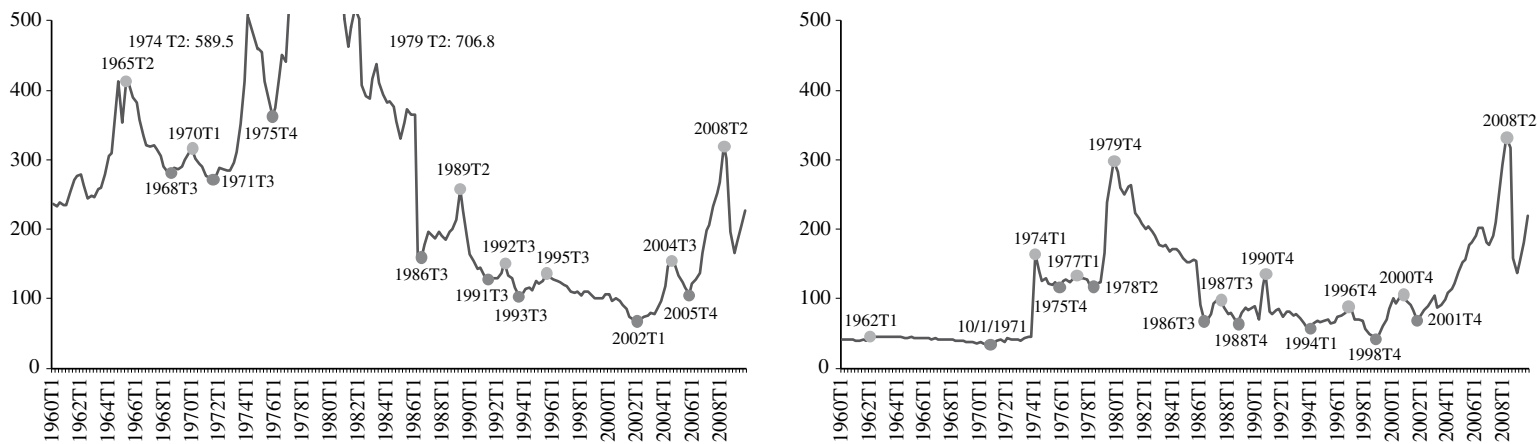

Source: prepared by the authors on the basis of data obtained from the United Nations Conference on Trade and Development (UNCTAD). Note: The number next to the letter T indicates the quarter (trimestre) of the year; for example: 1969 T4 corresponds to the fourth quarter. 
ANNEX 2

Estimation of convergence measures

TABLE A2.1

Classical unit-root tests 1960 Q1 - 2009 Q4

\begin{tabular}{|c|c|c|c|c|c|c|c|c|}
\hline \multirow{3}{*}{$\begin{array}{l}\text { Commodity } \\
\text { General index }\end{array}$} & \multicolumn{4}{|c|}{ Augmented Dickey-Fuller } & \multicolumn{4}{|c|}{ Phillips-Perron } \\
\hline & \multicolumn{4}{|c|}{ Levels First differences } & \multicolumn{4}{|c|}{ Levels First differences } \\
\hline & -1.79 & & -8.10 & $* * *$ & -1.56 & & -7.92 & $* * *$ \\
\hline Food products & -1.57 & & -9.41 & $* * *$ & -1.46 & & -9.34 & $* * *$ \\
\hline Food & -1.76 & & -8.93 & $* * *$ & -1.60 & & -8.82 & $* * *$ \\
\hline Wheat & -1.98 & & -11.17 & $* * *$ & -1.88 & & -11.15 & $* * *$ \\
\hline Maize & -3.20 & $*$ & -10.92 & $* * *$ & -1.66 & & -10.55 & $* * *$ \\
\hline Rice & -2.01 & & -8.96 & $* * *$ & -1.34 & & -8.29 & $* * *$ \\
\hline Sugar & -3.00 & ** & -9.29 & $* * *$ & -2.50 & & -8.91 & $* * *$ \\
\hline Beef & -0.86 & & -7.59 & $* * *$ & -1.02 & & -12.91 & $* * *$ \\
\hline Bananas & -2.02 & & -10.99 & $* * *$ & -5.76 & $* * *$ & -36.00 & $* * *$ \\
\hline Soya meat & -3.71 & $* *$ & -10.59 & $* * *$ & -2.04 & & -10.41 & $* * *$ \\
\hline Fish meal & -2.46 & & -7.92 & $* * *$ & -2.81 & $*$ & -7.72 & $* * *$ \\
\hline Tropical drinks & -1.72 & & -9.62 & $* * *$ & -1.55 & & -9.67 & $* * *$ \\
\hline Coffee (Colombia) & -1.75 & & -7.32 & $* * *$ & -1.85 & & -10.67 & $* * *$ \\
\hline Coffee (Brazil) & -1.94 & & -10.68 & $* * *$ & -1.69 & & -10.72 & $* * *$ \\
\hline Cocoa & -1.90 & & -10.00 & $* * *$ & -1.81 & & -9.99 & $* * *$ \\
\hline Oils and oilseeds & -3.26 & $*$ & -10.10 & $* * *$ & -1.90 & & -10.09 & $* * *$ \\
\hline Soybeans & -3.35 & $*$ & -10.85 & $* * *$ & -1.50 & & -11.84 & $* * *$ \\
\hline Soya oil & -3.25 & $*$ & -10.21 & $* * *$ & -2.10 & & -10.25 & $* * *$ \\
\hline Sunflower oil & -3.42 & $*$ & -9.34 & $* * *$ & -1.94 & & -8.60 & $* * *$ \\
\hline Agricultural raw materials & -3.32 & $*$ & -8.43 & $* * *$ & -2.16 & & -6.89 & $* * *$ \\
\hline Tobacco & -3.10 & & -8.70 & $* * *$ & -1.68 & & -8.63 & $* * *$ \\
\hline Cotton & -3.59 & $* *$ & -10.69 & $* * *$ & -2.70 & & -10.42 & $* * *$ \\
\hline Rubber & -2.87 & & -6.93 & $* * *$ & -1.92 & & -10.10 & $* * *$ \\
\hline Minerals and metals & -2.28 & & -9.10 & $* * *$ & -1.46 & & -8.62 & $* * *$ \\
\hline Iron & -0.56 & & -14.14 & $* * *$ & -0.87 & & -14.22 & $* * *$ \\
\hline Aluminium & -5.15 & $* * *$ & -8.09 & $* * *$ & -2.54 & & -6.91 & $* * *$ \\
\hline Copper & -3.22 & $* *$ & -10.21 & $* * *$ & -2.75 & $*$ & -9.66 & $* * *$ \\
\hline Nickel & -3.48 & $* * *$ & -9.46 & $* * *$ & -3.04 & $* *$ & -9.38 & $* * *$ \\
\hline Lead & -1.84 & & -8.68 & $* * *$ & -2.18 & & -8.34 & $* * *$ \\
\hline Zinc & -3.80 & $* * *$ & -8.80 & $* * *$ & -3.10 & $* *$ & -8.27 & $* * *$ \\
\hline Tin & -1.56 & & -10.75 & $* * *$ & -1.42 & & -10.42 & $* * *$ \\
\hline Gold & -2.97 & $* *$ & -4.30 & $* * *$ & -2.24 & & -10.61 & $* * *$ \\
\hline Silver & -1.45 & & -11.11 & $* * *$ & -1.67 & & -11.11 & $* * *$ \\
\hline Oil & -1.62 & & -12.44 & $* * *$ & -1.56 & & -12.40 & $* * *$ \\
\hline
\end{tabular}

Source: prepared by the authors on the basis of data obtained from the United Nations Conference on Trade and Development (UNCTAD). Note: The asterisks indicate that the null hypothesis of a unit root can be rejected at the $10 \%(*), 5 \%(* *)$ or $1 \%(* * *)$ level. The specification of each hypothesis test (number of lags, presence of trend, and other items) was chosen using the Schwarz information criteria. 
TABLE A2.2

Estimation of the autoregressive parameter and measures of persistence 1960 Q1 - 2009 Q4

\begin{tabular}{|c|c|c|c|c|c|c|c|c|c|c|}
\hline & \multicolumn{5}{|c|}{ Levels } & \multicolumn{5}{|c|}{ First differences } \\
\hline & OLS & & UEM & CIRF & ML & OLS & & UEM & CIRF & ML \\
\hline General index & $\begin{array}{c}0.98 \\
(0.02)\end{array}$ & $* * *$ & 1.00 & $\infty$ & $\infty$ & $\begin{array}{c}0.49 \\
(0.06)\end{array}$ & $* * *$ & 0.51 & 2.03 & 1.02 \\
\hline Food products & $\begin{array}{c}0.98 \\
(0.02)\end{array}$ & $* * *$ & 1.00 & $\infty$ & $\infty$ & $\begin{array}{c}0.38 \\
(0.07)\end{array}$ & $* * *$ & 0.39 & 1.65 & 0.74 \\
\hline Food & $\begin{array}{c}0.98 \\
(0.02)\end{array}$ & $* * *$ & 1.00 & $\infty$ & $\infty$ & $\begin{array}{c}0.42 \\
(0.07)\end{array}$ & $* * *$ & 0.44 & 1.77 & 0.84 \\
\hline Wheat & $\begin{array}{c}0.95 \\
(0.02)\end{array}$ & $* * *$ & 0.98 & 54.07 & 37.13 & $\begin{array}{c}0.22 \\
(0.07)\end{array}$ & $* * *$ & 0.24 & 1.31 & 0.48 \\
\hline Maize & $\begin{array}{c}0.94 \\
(0.03)\end{array}$ & $* * *$ & 0.97 & 34.50 & 23.56 & $\begin{array}{c}0.24 \\
(0.07)\end{array}$ & $* * *$ & 0.25 & 1.34 & 0.51 \\
\hline Rice & $\begin{array}{c}0.97 \\
(0.02)\end{array}$ & $* * *$ & 1.00 & $\infty$ & $\infty$ & $\begin{array}{c}0.42 \\
(0.07)\end{array}$ & $* * *$ & 0.43 & 1.77 & 0.83 \\
\hline Sugar & $\begin{array}{c}0.95 \\
(0.02)\end{array}$ & $* * *$ & 0.99 & 115.03 & 79.39 & $\begin{array}{c}0.39 \\
(0.07)\end{array}$ & $* * *$ & 0.40 & 1.68 & 0.76 \\
\hline Beef & $\begin{array}{c}0.95 \\
(0.02)\end{array}$ & $* * *$ & 0.99 & 95.36 & 65.75 & $\begin{array}{c}0.08 \\
(0.07)\end{array}$ & & 0.09 & 1.10 & 0.29 \\
\hline Bananas & $\begin{array}{c}0.69 \\
(0.05)\end{array}$ & $* * *$ & 0.71 & 3.48 & 2.04 & $\begin{array}{l}-0.32 \\
(0.07)\end{array}$ & $* * *$ & -0.32 & - & - \\
\hline Soya meat & $\begin{array}{c}0.93 \\
(0.03)\end{array}$ & $* * *$ & 0.96 & 25.49 & 17.32 & $\begin{array}{c}0.27 \\
(0.07)\end{array}$ & $* * *$ & 0.29 & 1.40 & 0.56 \\
\hline Fish meal & $\begin{array}{c}0.96 \\
(0.02)\end{array}$ & $* * *$ & 1.00 & $\infty$ & $\infty$ & $\begin{array}{c}0.54 \\
(0.06)\end{array}$ & $* * *$ & 0.56 & 2.26 & 1.19 \\
\hline Tropical drinks & $\begin{array}{c}0.97 \\
(0.02)\end{array}$ & $* * *$ & 1.00 & $\infty$ & $\infty$ & $\begin{array}{c}0.36 \\
(0.07)\end{array}$ & $* * *$ & 0.37 & 1.59 & 0.70 \\
\hline Coffee (Colombia) & $\begin{array}{c}0.96 \\
(0.02)\end{array}$ & $* * *$ & 1.00 & $\infty$ & $\infty$ & $\begin{array}{c}0.26 \\
(0.07)\end{array}$ & $* * *$ & 0.28 & 1.39 & 0.54 \\
\hline Coffee (Brazil) & $\begin{array}{c}0.96 \\
(0.02)\end{array}$ & $* * *$ & 1.00 & $\infty$ & $\infty$ & $\begin{array}{c}0.26 \\
(0.07)\end{array}$ & $* * *$ & 0.28 & 1.39 & 0.54 \\
\hline Cocoa & $\begin{array}{c}0.98 \\
(0.02)\end{array}$ & $* * *$ & 1.00 & $\infty$ & $\infty$ & $\begin{array}{c}0.32 \\
(0.07)\end{array}$ & $* * *$ & 0.33 & 1.50 & 0.63 \\
\hline Oils and oilseeds & $\begin{array}{c}0.95 \\
(0.02)\end{array}$ & $* * *$ & 0.98 & 58.75 & 40.37 & $\begin{array}{c}0.31 \\
(0.07)\end{array}$ & $* * *$ & 0.33 & 1.49 & 0.62 \\
\hline Soya beans & $\begin{array}{c}0.93 \\
(0.03)\end{array}$ & $* * *$ & 0.96 & 23.22 & 15.74 & $\begin{array}{c}0.18 \\
(0.07)\end{array}$ & $* *$ & 0.19 & 1.24 & 0.42 \\
\hline Soya oil & $\begin{array}{c}0.94 \\
(0.02)\end{array}$ & $* * *$ & 0.98 & 46.78 & 32.08 & $\begin{array}{c}0.30 \\
(0.07)\end{array}$ & $* * *$ & 0.32 & 1.47 & 0.61 \\
\hline Sunflower oil & $\begin{array}{c}0.95 \\
(0.02)\end{array}$ & $* * *$ & 0.99 & 77.90 & 53.65 & $\begin{array}{c}0.38 \\
(0.07)\end{array}$ & $* * *$ & 0.40 & 1.66 & 0.75 \\
\hline Agricultural raw materials & $\begin{array}{c}0.96 \\
(0.02)\end{array}$ & $* * *$ & 1.00 & $\infty$ & $\infty$ & $\begin{array}{c}0.49 \\
(0.06)\end{array}$ & $* * *$ & 0.50 & 2.02 & 1.01 \\
\hline Tobacco & $\begin{array}{c}0.97 \\
(0.02)\end{array}$ & $* * *$ & 1.00 & $\infty$ & $\infty$ & $\begin{array}{c}0.44 \\
(0.06)\end{array}$ & $* * *$ & 0.46 & 1.84 & 0.88 \\
\hline Cotton & $\begin{array}{c}0.93 \\
(0.03)\end{array}$ & $* * *$ & 0.96 & 23.84 & 16.18 & $\begin{array}{c}0.25 \\
(0.07)\end{array}$ & $* * *$ & 0.27 & 1.37 & 0.53 \\
\hline Rubber & $\begin{array}{c}0.95 \\
(0.02)\end{array}$ & $* * *$ & 0.99 & 73.34 & 50.49 & $\begin{array}{c}0.31 \\
(0.07)\end{array}$ & $* * *$ & 0.32 & 1.48 & 0.62 \\
\hline Minerals and metals & $\begin{array}{c}0.98 \\
(0.02)\end{array}$ & $* * *$ & 1.00 & $\infty$ & $\infty$ & $\begin{array}{c}0.39 \\
(0.07)\end{array}$ & $* * *$ & 0.41 & 1.69 & 0.78 \\
\hline Iron & $\begin{array}{c}1.00 \\
(0.02)\end{array}$ & $* * *$ & - & - & - & $\begin{array}{l}-0.03 \\
(0.07)\end{array}$ & & -0.02 & - & - \\
\hline Aluminium & $\begin{array}{c}0.92 \\
(0.03)\end{array}$ & $* * *$ & 0.95 & 19.65 & 13.27 & $\begin{array}{c}0.49 \\
(0.06)\end{array}$ & $* * *$ & 0.51 & 2.04 & 1.03 \\
\hline
\end{tabular}




\begin{tabular}{|c|c|c|c|c|c|c|c|c|c|c|}
\hline & \multicolumn{5}{|c|}{ Levels } & \multicolumn{5}{|c|}{ First differences } \\
\hline & OLS & & UEM & CIRF & ML & OLS & & UEM & CIRF & ML \\
\hline Copper & $\begin{array}{c}0.94 \\
(0.03)\end{array}$ & $* * *$ & 0.98 & 49.77 & 34.15 & $\begin{array}{c}0.30 \\
(0.07)\end{array}$ & $* * *$ & 0.31 & 1.46 & 0.60 \\
\hline Nickel & $\begin{array}{c}0.95 \\
(0.02)\end{array}$ & $* * *$ & 0.98 & 58.68 & 40.33 & $\begin{array}{c}0.37 \\
(0.07)\end{array}$ & $* * *$ & 0.39 & 1.63 & 0.73 \\
\hline Lead & $\begin{array}{c}0.97 \\
(0.02)\end{array}$ & $* * *$ & 1.00 & $\infty$ & $\infty$ & $\begin{array}{c}0.40 \\
(0.07)\end{array}$ & $* * *$ & 0.42 & 1.72 & 0.79 \\
\hline Zinc & $\begin{array}{c}0.94 \\
(0.02)\end{array}$ & $* * *$ & 0.98 & 41.95 & 28.73 & $\begin{array}{c}0.42 \\
(0.07)\end{array}$ & $* * *$ & 0.44 & 1.78 & 0.84 \\
\hline Tin & $\begin{array}{c}0.97 \\
(0.02)\end{array}$ & $* * *$ & 1.00 & $\infty$ & $\infty$ & $\begin{array}{c}0.26 \\
(0.07)\end{array}$ & $* * *$ & 0.27 & 1.37 & 0.53 \\
\hline Gold & $\begin{array}{c}0.97 \\
(0.02)\end{array}$ & $* * *$ & 1.00 & $\infty$ & $\infty$ & $\begin{array}{c}0.20 \\
(0.08)\end{array}$ & $* *$ & 0.22 & 1.28 & 0.45 \\
\hline Silver & $\begin{array}{c}0.97 \\
(0.02)\end{array}$ & $* * *$ & 1.00 & $\infty$ & $\infty$ & $\begin{array}{c}0.11 \\
(0.08)\end{array}$ & & 0.13 & 1.15 & 0.34 \\
\hline Oil & $\begin{array}{c}0.96 \\
(0.02)\end{array}$ & $* * *$ & 1.00 & $\infty$ & $\infty$ & $\begin{array}{c}0.11 \\
(0.07)\end{array}$ & & 0.13 & 1.15 & 0.34 \\
\hline
\end{tabular}

Source: prepared by the authors on the basis of data obtained from the United Nations Conference on Trade and Development (UNCTAD). Notes: OLS = ordinary least squares; UEM = unbiased estimate of the mean; $\mathrm{CIRF}=$ cumulative impulse-response function; $\mathrm{ML}=$ half life. The estimated parameter is $\alpha$ of equation (1). The figures in parentheses are the standard deviations of the estimators. The asterisks indicate that the coefficient is significant at the $10 \%(*), 5 \%(* *)$ or $1 \%(* * *)$ level. 


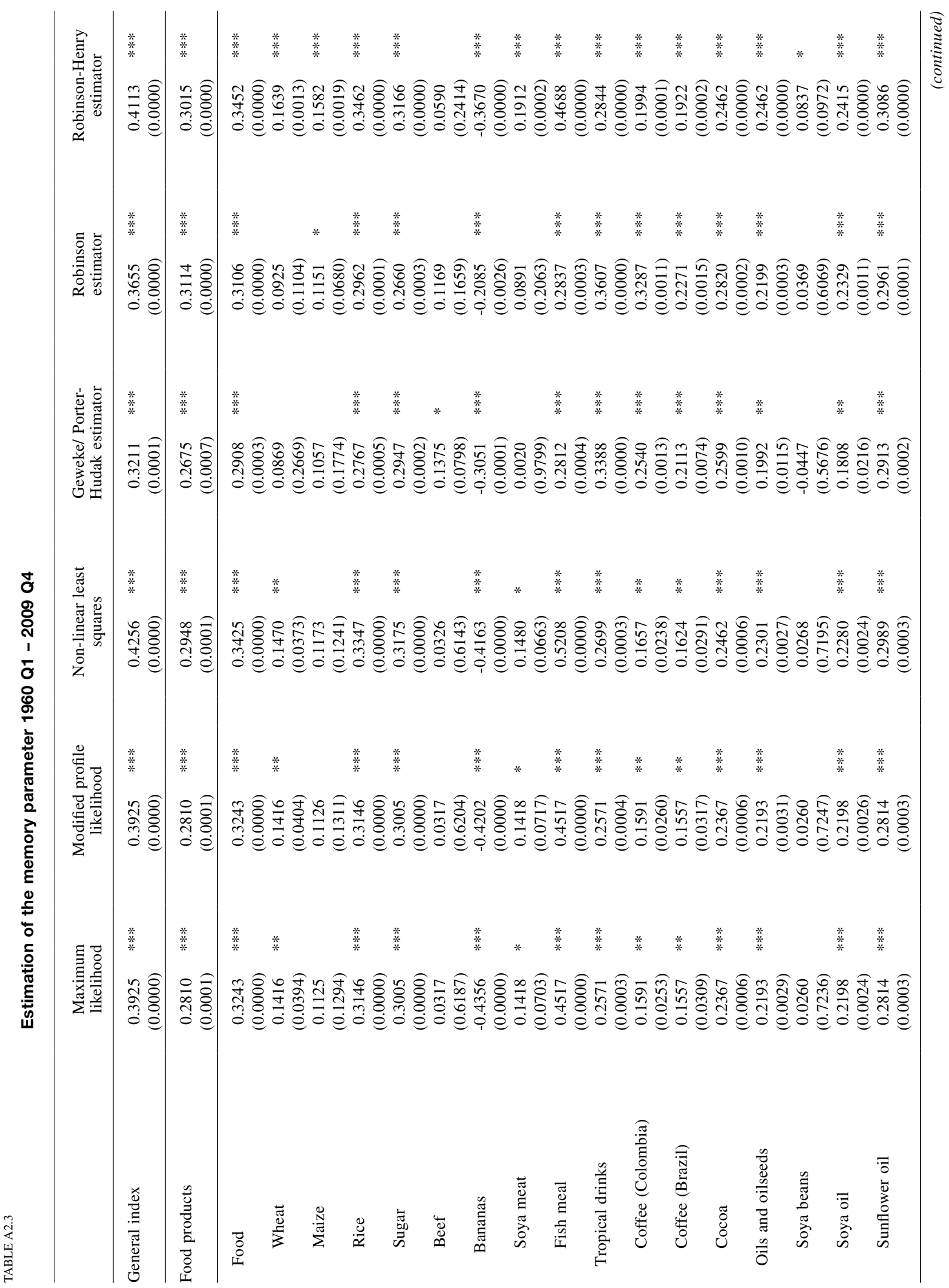




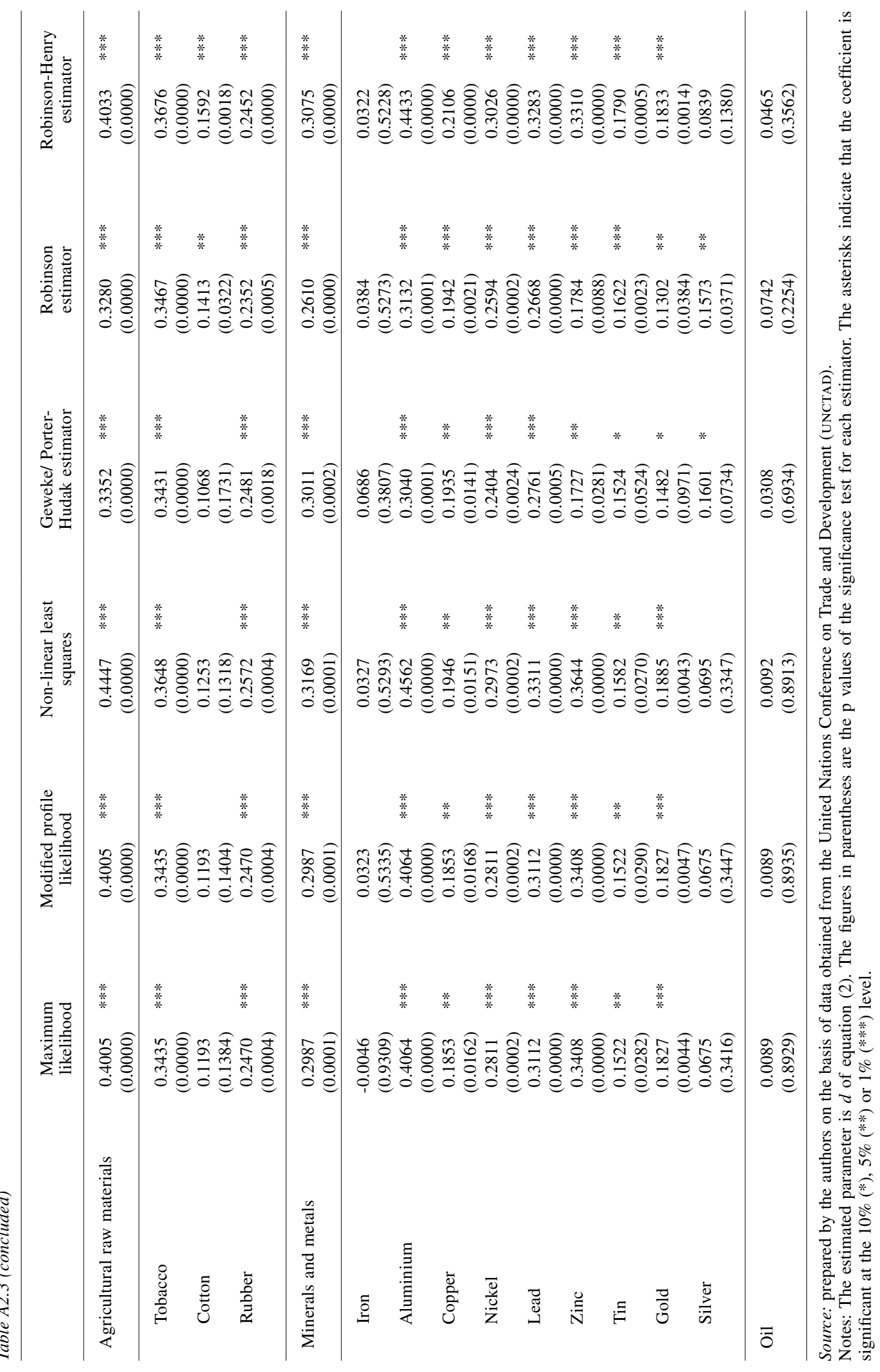




\section{Bibliography}

Andrews, Donald (1993), "Exactly median-unbiased estimation of first order autoregressive/unit root models", Econometrica, vol. 61, No. 1, Washington, D.C., Econometric Society.

Andrews, Donald and Hong-Yuan Chen (1994), "Approximately median-unbiased estimation of autoregressive models", Journal of Business and Economic Statistics, vol. 12, No. 2, Alexandria, American Statistical Association.

Bello, Omar and Rodrigo Heresi (2008), "El auge reciente de precios de los productos básicos en perspectiva histórica", Macroeconomía del desarrollo series, No. 71 (LC/L.2975-P), Santiago, Chile, Economic Commission for Latin America and the Caribbean (ECLAC). United Nations publication, Sales No. S.08.II.G.84.

Bello, Omar, Rodrigo Heresi and Omar Zambrano (2008), "The present decade boom of commodity prices in historical perspective and its macroeconomic effects in Latin America", Santiago, Chile, Economic Commission for Latin America and the Caribbean (ECLAC), unpublished.

Bry, Gerhard and Charlotte Boschan (1971), Cyclical Analysis of Time Series: Selected Procedures and Computer Programs, Cambridge, Massachusetts, New York, National Bureau of Economic Research.

Caballero, Ricardo, Emmanuel Farhi and Pierre-Olivier Gourinchas (2008), "Financial crash, commodity prices, and global imbalances", Brookings Papers on Economic Activity, Washington, D.C., Brookings Institution Press.

Cashin, Paul and John McDermott (2002), "The long-run behavior of commodity prices: small trends and big variability", IMF Staff Papers, vol. 49, No. 2, Washington, D.C., International Monetary Fund.

Cashin, Paul, John McDermott and Alasdair Scott (1999a), "Booms and slumps in world commodity prices", IMF Working Papers, No. 155, Washington, D.C., International Monetary Fund (IMF). (1999b), "The myth of co-moving commodity prices", Discussion Paper Series, No. G99/8, Wellington, Reserve Bank of New Zealand.

Cashin, Paul, Hog Liang and John McDermott (2000), "How persistent are shocks to world commodity prices?", IMF Staff Papers, vol. 47, No. 2, Washington, D.C., International Monetary Fund.

Cuddington, John (1992), "Long-run trends in 26 primary commodities: a disaggregated look at the Prebisch-Singer hypothesis", Journal of Development Economics, vol. 39, No. 2, Amsterdam, Elsevier.

Cuddington, John and Carlos Urzúa (1989), "Trends and cycles in the net Barter terms of trade: a new approach", Economic Journal, vol. 99, No. 396, London, Royal Economic Society.

Cuddington, John, Rodney Ludema and Shamila Jayasuriya (2002), "Prebisch-Singer Redux", Working Paper, No. 140, Santiago, Chile, Central Bank of Chile, February.

Davis, Steven and John Haltiwanger (2001), "Sectoral job creation and destruction responses to oil price changes", Journal of Monetary Economics, vol. 48, $\mathrm{N}^{\circ} 3$, Amsterdam, Elsevier.
Deaton, Angus (1999), "Commodity prices and growth in Africa", Journal of Economic Perspectives, vol. 13, No. 3, Nashville, Tennessee, American Economic Association.

Deaton, Angus and Guy Laroque (1992), "On the behaviour of commodity prices", Review of Economic Studies, vol. 59, № 1 , Oxford, Blackwell Publishing.

Doornik, Jurgen and Marius Ooms (2004), "Inference and forecasting for ARFIMA models, with an application to US and UK inflation", Studies in Non-linear Dynamics and Econometrics, vol. 8, No. 2, Berkeley, Berkeley Electronic Press.

ECLAC (Economic Commission for Latin America and the Caribbean) (2008), Social Panorama of Latin America, 2008 (LC/ G.2402-P), Santiago, Chile. United Nations publication, Sales No. E.08.II.G.89.

(2007), Social Panorama of Latin America, 2007 (LC/ G.2351-P), Santiago, Chile. United Nations publication, Sales No. E.07.II.G.124.

(various years), Economic Survey of Latin America and the Caribbean, Santiago, Chile.

(various years), Social Panorama of Latin America, Santiago, Chile.

Grilli, Enzo and Maw Yang (1988), "Primary commodity prices, manufactured goods prices, and the terms of trade of developing countries: what the long run shows", The World Bank Economic Review, vol. 2, Washington, D.C., World Bank.

Hamilton, James (1996), "This is what happened to the oil pricemacroeconomy relationship", Journal of Monetary Economics, vol. 38, No. 2, Amsterdam, Elsevier.

Herrera, Ingrid and Ramón Pineda (2006), "Booms de la cesta petrolera venezolana", Caracas, Central Bank of Venezuela, unpublished.

Ocampo, José Antonio and María Ángela Parra (2003), "The terms of trade for commodities in the twentieth century", CEPAL Review, No. 79 (LC/G.2200), Santiago, Chile, April.

Pyndick, Robert and Julio Rotemberg (1990), "The excess of comovements of commodity prices", The Economic Journal, vol. 100, No. 403, London, Royal Economic Society, December.

Reinhart, Carmen and Peter Wickham (1994), "Commodity prices: cyclical weakness or secular decline", IMF Staff Papers, vol. 41, Washington, D.C., International Monetary Fund (IMF).

Rodríguez, Francisco (2009), “Está América Latina sumida en una trampa de pobreza?", Macroeconomía del desarrollo series, No. 80 (LC/L.3017-P), Santiago, Chile, Economic Commission for Latin America and the Caribbean (ECLAC). United Nations publication, Sales No. S.09.II.G.27.

Southwood, Jim (2008), “CRU's new process for managing copper price risk", presentation at the CRU's $7^{\text {th }}$ World Copper Conference, April.

Toledo, Manuel (2008), "Understanding business cycles in Latin America", Santiago, Chile, Economic Commission for Latin America and the Caribbean (ECLAC), unpublished. 